\title{
The Factors Determining the Dividend Policy of Financial Firms Listed on the Borsa Istanbul
}

\author{
Erhan Kılınçarslan* \\ İstanbul Gelişim University
}

\begin{abstract}
This study examines the factors determining the dividend policy of financial firms in Turkey. Analysing a panel dataset of 80 financial firms listed on the Borsa Istanbul over the period 2009-2016, the results reveal that profitability, debt, growth, firm size, liquidity and asset tangibility are the financial characteristics that have significant effects on dividend decisions. The findings also show that foreign shareholders are the only owners influencing financial firms in setting dividend payments, whereas board size, family members on the board and independent directors have significant impacts on dividend policies of financial corporations. Overall, the study results suggest that the major factors determining dividend policy decisions of financial firms in Turkey are similar to those of the industrial (non-financial) firms documented in the literature.
\end{abstract}

Keywords: dividend policy, Borsa Istanbul, financial firms, Turkey.

JEL Classification: G2, G3, G35.

\section{Borsa İstanbul'da İşlem Gören Finansal Firmaların Temettü Politikalarını Belirleyen Faktörler}

\section{Özet}

Bu çalışma, Türkiye' deki finansal firmaların temettü politikalarını belirleyen faktörleri incelemektedir. Borsa İstanbul'da işlem gören 80 finansal firmanın, 2009-2016 dönemine ait, panel verilerinin analizi sonucunda, kârlılık, borç, büyüme, firma büyüklüğü, likidite ve maddi duran varlıkların oranı, temettü kararlarında önemli etkiye sahip finansal özellikler olarak ortaya çıkmaktadır. Bulgular ayrıca sadece yabancı hissedarların finansal firmaların temettü ödemelerini etkileyen sahiplik çeşidi olduğunu göstermekle birlikte, yönetim kurulu büyüklüğünün, yönetim kurulundaki aile üyelerinin ve bağımsız yöneticilerin finans şirketlerinin temettü politikaları üzerine önemli etkilerini tespit etmiştir. Genel olarak, çalışma sonuçları Türkiye'deki finansal firmaların temettü politikalarını belirleyen başlıca faktörlerin, literatürde belirtilen ve sanayi (finansal olmayan) firmalarını etkileyen faktörlere benzer olduğunu göstermektedir.

Anahtar Kelimeler: temettü politikasl, Borsa İstanbul, finansal firmalar, Türkiye.

JEL Sinıflandirmasi: G2, G3, G35.

* Erhan Kılınçarslan is an Assistant Professor in the Department of International Trade at İstanbul Gelişim University, Cihangir Mahallesi, Şehit Jandarma Komando Er Hakan Öner Sokak, No:1, 34310 Avcılar, İstanbul, Turkey. Email: ekilincarslan@gelisim.edu.tr 
$\mathrm{D}$ ividend policy refers to the managerial decisions about whether to distribute the company's earnings to shareholders or retain them for reinvestments in the company. Hence, dividend policy is closely related to other financial decisions, such as investment, capital structure, and mergers and acquisitions policies (Smith and Watts, 1992; Barclay et al., 1995; Allen and Michaely, 2003). In this respect, the process in determining the size and pattern of distributions to shareholders is an important aspect of corporate financial management and has significant implications for common share prices, and therefore the wealth of shareholders over time (Glen et al., 1995; Lease et al., 2000). Accordingly, economists, financial analysts and scholars have paid a great deal of attention to dividend policy and attempted to answer questions such as why some companies pay dividends, and some do not, why investors care, and to what extent dividend policy may affect a firm's market value. However, despite voluminous theorizing, countless empirical research and extensive debate, the actual motivation for paying dividends still remains unsolved (Baker and Powell, 1999; Baker et al., 2002). Black (1976, p.5) once describes this lack of consensus as the "dividend puzzle" and notes that "The harder we look at the dividend picture, the more it seems like a puzzle, with pieces that just don't fit together." Although Black (1976) came to this conclusion four decades ago, his observation still seems valid as dividend policy continues to remain controversial - in fact, Brealey and Myers (2003) list dividend policy as one of the ten important unsolved issues in corporate finance.

As Baker et al. $(2006,2008)$ point out, one of the main reasons leading to this failure is that the majority of previous studies have been trying hard to develop a universal or "one-size-fits-all" explanation for dividends based on a single aspect. However, corporate dividend decisions are sensitive to various factors, such as financial characteristics (i.e., profitability, growth, and size), ownership structures (i.e., concentrated or dispersed), and may vary across countries (i.e., developed or emerging markets) and even over time (La Porta et al., 2000; Fama and French, 2001; Aivazian et al., 2003; Baker and Wurgler, 2004; Ferris et al., 2006). Furthermore, the extant research on corporate dividend policy has mostly focused on non-financial firms but excluded financial institutions (i.e., banks, insurers, pension funds and investment trusts). For example, many renowned and influential studies, such as Lintner (1956), Rozeff (1982), La Porta et al. (2000), Fama and French (2001), Baker and Wurgler (2004), Grinstein and Michaely (2005), among others, truncate their sample by deleting financial firms, due to the different nature of financial corporations as compared to industrial (nonfinancial) companies. This is because of their different role in capital markets, tighter sector regulations, different capital structures, higher financial leverage, and different accounting practices. Nevertheless, financial firms are money managers, who directly invest for themselves or act as agents on behalf of other investors, and generally hold larger amounts of investment funds. Their activities include providing liquidity to markets (i.e., offering credit), mobilizing savings, diversifying risk, and facilitating exchange. Besides, financial institutions are often encouraged to take an active monitoring role on the businesses as a financial intermediary. Hence, they are crucial players for economic prosperity, growing investment and improving corporate governance practices in capital 
markets. Considering their importance within the economy, the exclusion of financial sector companies is another major concern in the dividend literature.

From a practical perspective, many financial firms indeed pay cash dividends and thus it is vital to examine the dividend payment decisions of financial institutions in identifying the factors explaining the dividend policy behaviour of this important sector. Although there is some research on dividend payout of financial firms separately (see, for instance, Gupta and Walker, 1975; Dutta, 1999; Dickens et al., 2003; Theis and Dutta, 2009; Imran et al., 2013; Ashraf and Zheng, 2015), the evidence is relatively limited and more work is needed in this area. The purpose of this paper is, therefore, to provide further information about the dividend policy of financial firms by identifying the most important factors affecting their dividend decisions, and to examine whether these factors are consistent with those of the non-financial firms documented in the literature.

In particular, the paper focuses on Turkey and empirically investigates the dividend policies of financial firms listed on the Borsa Istanbul (BIST). Turkey presents a unique case for the study, because it is one of the most important emerging economies worldwide, strategically located between Europe and the Middle-East, and a candidate member of the European Union (EU). Unlike well-developed capital markets, such as the US and the UK, where the ownership of public firms is widely dispersed and corporations rely on arm's length contracting by uniformed investors, the corporate ownership in Turkey is highly concentrated, mostly dominated by families who generally own business affiliations under the legal form of a "holding company" (Gürsoy and Aydoğan, 1999; Yurtoğlu, 2003) and the Turkish capital market is characterised by closely-held bankfinanced firms that are mainly part of those bigger family-owned holding companies (Aivazian et al., 2003; Ertürk, 2003). Turkey has also implemented major reforms ${ }^{[1]}$ in the early 2000s in compliance with the EU directives and best-practice international standards for a better working of the market economy, outward-orientation, and globalization. Turkish regulators have further made significant changes in the regulatory framework of cash dividend payment rules by abolishing mandatory minimum dividend payout requirements in the late 2000s, which gave BIST corporate managers the freedom to make their own dividend policy decisions. Accordingly, this study contributes to the dividend literature new empirical evidence that provides more insight into the determinants of the dividend policy of financial firms in the emerging Turkish market. Moreover, in addition to prior research on dividends in Turkey, which mostly considers non-financial firms (i.e., Adaoğlu, 2000, 2008; Kirkulak and Kurt, 2010; Al-Najjar and Kilincarslan, 2016, 2017), the present study, by examining financial firms, helps draw a more complete picture of the dividend policy of all firms trading in the BIST. To the best of the author's knowledge, this paper provides the first comprehensive research on

${ }^{[1]}$ Some of these major developments include adopting International Financial Reporting Standards (IFRS), publishing the Capital Markets Board of Turkey's Corporate Governance Principles, reforming the public and private banking system, and augmenting the scrutiny and supervisory framework to minimize credit risk concentration and avoid insider lending, accelerating privatization of state-owned enterprises, and creating private pensions and mutual funds to increase monitoring on public firms' corporate governance (Aksu and Kösedağ, 2006; CMB, 2003; IIF, 2005). 
the Turkish market: it identifies the factors determining the dividend policy of financial firms based on financial characteristics, ownership and board structures.

The paper proceeds as follows. The next section reviews the literature and develops the hypotheses. This is followed by a section that describes the methodology (the data sample, research variables and models). The subsequent section illustrates and discusses the empirical results, while the final section concludes the paper.

\section{Literature Review and Hypotheses Development}

\section{Theoretical Background}

Miller and Modigliani (1961) show that no dividend policy is superior to another under perfect capital market assumptions and therefore posit that dividend payments are irrelevant to the firm value (the "dividend irrelevance theory"). However, real world capital markets are subject to various imperfections (i.e., differential tax rates, information asymmetries, transaction costs, risks and agency problems) and such imperfections make their arguments highly debatable. In fact, "the bird-in-the-hand" theory argues that more certainty is attached to dividend payments received (cash in the hand) today, instead of dividend retention for reinvestments in projects whose future earnings are uncertain. Hence, shareholders prefer dividend payments and investors value firms with higher dividend payouts more highly, because dividends are less risky than capital gains (Gordon and Shapiro, 1956; Gordon, 1959).

The "signalling theory" is one of the most popular explanations in favour of dividends, indicating that corporate managers have a better knowledge about the firm's true value than outside shareholders and investors, who can only obtain the public information. Accordingly, corporate managers can use dividends as a tool to signal their superior information about the firm to outsiders, which in turn reduces information asymmetries - if managers are confident about their firm's future performance, they distribute larger cash dividends to shareholders as a credible signal (Bhattacharya, 1979; John and Williams, 1985; Miller and Rock, 1985). Furthermore, the "agency cost theory" points out the role of dividends in controlling problems associated with the separation of management and ownership, and the differences in managerial and shareholder priorities. It posits that dividend payments reduce the free cash from the managers' control that they may spend for unprofitable investments or even misuse for their own consumption, and also force managers to enter the external capital markets for additional funding, and thus increase the screening and monitoring by the market (Jensen and Meckling, 1976; Rozeff, 1982; Easterbrook, 1984; Jensen, 1986). Consequently, an effective dividend policy helps to minimize agency problems and enhance the firm value.

On the other hand, there are other explanations claiming that dividend payments can have negative effects on the firm value and shareholder wealth. From the "tax-preference theory" perspective, in the presence of differential tax rates between dividends and capital gains, investors who receive favourable tax treatment on capital gains prefer shares with non or low dividends, because higher dividend payments increase their tax 
burden (Brennan, 1970; Elton and Gruber, 1970; Litzenberger and Ramaswamy, 1979). Similarly, the "transaction cost theory" asserts that firms may face the heavy transaction costs of raising external funds (i.e., underwrite fees, administration costs, management time and legal expenses) for possible investment projects, after using cheap and easily accessible internal funds to pay dividends (Bhattacharya, 1979; Miller and Rock, 1985; Rozeff, 1982).

Moreover, the "pecking order theory" contends that firms should finance new investments with retained earnings first, then with debt, and finally by raising equity financing (but only in extreme cases). Therefore, this theory predicts a negative relationship between dividends and investment opportunities, since reducing the amounts of dividends is one obvious way to prevent external financing and make more use of internally generated funds for investments (Myers, 1984; Myers and Majluf, 1984). According to the "maturity hypothesis" (Grullon et al., 2002), higher dividend distributions are a sign of change in a firm's life cycle. More specifically, firms are likely to pay higher dividends as they transit from growth to a more mature phase, where their investment opportunities and growth rates become slower or even decline, and they start generating larger amounts of free cash flows. La Porta et al. (2000) propose two alternative arguments based on the legal rights of outside shareholders and dividend payments, namely the "outcome model" and "substitute model" of dividends. Their first view suggests that under an effective system with strong protections, minorities use their legal powers to force firms to disgorge cash in the form of dividends, which are then an outcome of stronger legal rights, and hence prevent controlling owners to expropriate corporate wealth. However, the substitute model predicts that dividends are substitutes for weaker legal rights. By paying dividends, managers establish a reputation for good treatment of minority shareholders in countries with poor shareholder protection.

The above discussion briefly summarizes the main theoretical arguments of which some have been widely discussed and extensively tested in the hope of solving the dividend puzzle. This by no means covers the full set of theories of dividend policy as there are other standing views related to behavioural finance, such as the catering theory of dividends or the dividend clientele hypothesis. In addition, although each theory offers logical reasons for paying or not paying dividends on its own, they produce contradictory explanations as a whole. Hence, it is concluded that none of these theories describe the dividend puzzle single-handedly, confirming Frankfurter and Wood's (2003, p.167) statement that, "No theory based on the economic paradigm developed thus far completely explains the persistence of corporate dividend policy."

\section{Previous Studies on Determinants of Dividend Policy and Research Hypotheses}

Given that dividend decisions play an important role in the overall corporate strategy and firm value creation, the firm characteristics that determine dividend policy are of critical importance especially to financial managers who must set optimum policies. Identifying such determinants helps corporate policy makers to review their dividend practices, compare them with their counterparts, and allocate corporate earnings in a way that better increases firm value. From the investor perspective, there are different 
types of investors and portfolio managers who have heterogeneous preferences regarding the returns on their investments - for example, some might desire dividend income, whereas others might favour capital gains, or even a mixture of both. Hence, knowledge about firm characteristics determining dividend policy may assist investors and portfolio managers to detect companies with policies that best fit their dividend preferences for their investment targets. The analysis of the effects of firm characteristics on corporate dividend decisions will also provide useful information to financial scholars and researchers to better understand why some firms pay dividends while other firms do not, and properly appraise the issues that drive dividend practices in formulating theories and models to explain corporate dividend behaviour, thus enriching the finance literature concerning the dividend policy debate.

Since no single theory explains the dividend puzzle alone, some scholars have attempted to explore potential firm characteristics primarily influencing corporate dividend policy, reflecting on various theories in the related literature. These determinants include financial characteristics, ownership and board structures of firms. Accordingly, this sub-section reviews a set of selected determinants that are used in the prior research and considered as key factors generally shaping dividend payment decisions of nonfinancial firms - however, it is worth noting that several studies also apply some of these factors to financial firms, as discussed below. The sub-section further presents the corresponding research hypotheses based on the selected determinants, which might have been important factors in affecting dividend policies of financial firms in the Turkish market as well.

Financial characteristics. As dividends are the distribution of a firm's profits to its shareholders, it is not surprising that profitability is a major financial factor in determining dividend policy and profitable firms are more likely to pay dividends as compared to non-profitable firms. This is also consistent with the signalling theory of dividends, which argues that highly profitable firms pay larger cash dividends to convey their better financial position. In fact, empirical research (i.e., famous studies such as Fama and French, 2001; Aivazian et al., 2003; Ferris et al., 2006) reports a positive correlation between profitability and dividend payments. Contrarily, the dividend literature suggests that debt exerts a negative influence on dividend payout. From the transaction cost theory perspective, debt leads to financial charges and fixed costs that firms have to repay (i.e., interest payments) and the dependency on high degrees of external financing will increase the risk of firms' stocks. Thus, highly levered firms tend to maintain their earnings to lower external financing and are expected to pay none or low dividends (Miller and Rock, 1985; Rozeff, 1982; Manos, 2002). It is also argued that debt and dividends are alternative mechanisms in monitoring managers and controlling agency related problems (Jensen and Meckling, 1976; Jensen, 1986; Crutchley and Hansen, 1989). As they are substitute tools, the agency cost theory confirms the inverse relation between debt and dividends as well.

Another financial factor that has a negative impact on dividend payout is a firm's growth (investment) opportunities. For instance, Rozeff (1982), Holder et al. (1998), Fama and French (2001), Baker and Wurgler (2004) and Ferris et al. (2006) document 
that strong growth reduces both the likelihood and amounts of dividend payments. This negative association is supported by the pecking order theory because it predicts that firms with high growth opportunities will use their earnings first to finance those investments (then debt and equity issuance, given that investment requires more than the internally generated funds). Thus, high-growth firms should pay out low or no dividends (Myers, 1984; Myers and Majluf, 1984). Furthermore, firm size and firm age are two other important characteristics that appear to positively influence dividend policy. Large-sized firms face higher potential agency problems but have easier access to capital markets to raise external finance at lower costs, as compared to smaller firms (Lloyd et al., 1985). Considering the lower transaction costs and higher potential for agency problems, larger firms, therefore, distribute higher dividends as a controlling mechanism (Moh'd et al., 1995; Fama and French, 2001; Ferris et al., 2006). Similarly, as firms get older in terms of age, they tend to have steady earnings with declining investment opportunities, and thus are able to preserve a good level of funds. This allows them to pay higher dividends, consistent with the maturity hypothesis (Grullon et al., 2002; DeAngelo et al., 2006).

According to Jensen (1986), if firms have a great amount of free cash flow under managers' discretion, they should distribute large cash dividends to overcome agency costs of free cash flow. Then, this implies a positive correlation between free cash flow and dividend payout. Moreover, the liquidity of a firm can be another important financial factor for its dividend decisions. It is because firms with higher cash availability (high liquidity) are more likely to pay dividends than their counterparts with a liquidity crunch (Ho, 2003). By paying dividends, high-liquidity firms convey credible signals to the market that they are capable of paying their obligations easily and hence involve lower risk of default, consistent with the signaling theory. Finally, the prior research provides evidence that asset tangibility has a role in setting dividend policy, especially in developing markets. Aivazian et al. (2003) detect a negative relationship between tangibility of firm assets and dividends. They argue that larger fractions of long-term tangible assets decrease the proportions of short-term assets that can be used as collateral for short-term funding, and therefore reduce the borrowing capacity of firms where the main source of debt is short-term bank financing. This in turn forces firms to make more use of internally generated earning, while lessening the likelihood of paying dividends. The negative impact of asset tangibility on dividends is also reported by Ho (2003) and Al-Najjar (2009).

So far, the sub-section has reviewed the key financial determinants of dividend decisions based on the studies that examine only non-financial firms. Baker et al. (2008) study the views of Canadian managers of both financial and non-financial companies on dividends, and find that the perceptions of factors influencing dividend policy differ between managers of financial and non-financial companies. Despite this, a number of studies investigate the dividend behaviour of financials, more specifically banks, and report that similar financial characteristics are the significant factors in determining dividend policies of financials as for non-financials. For instance, Gupta and Walker (1975), Dickens et al. (2003), Imran et al. (2013), and Ashraf and Zheng (2015) present 
evidence that larger and more profitable banks pay higher dividends, whereas banks with greater growth opportunities pay lower dividends. Accordingly, based on the above discussion, the following hypotheses are formulated:

H1a: Profitability is positively related to the BIST financial firms' dividend policy.

H1b: Debt is negatively related to the BIST financial firms' dividend policy.

H1c: Growth is negatively related to the BIST financial firms' dividend policy.

H1d: Firm size is positively related to the BIST financial firms' dividend policy.

H1e: Firm age is positively related to the BIST financial firms' dividend policy.

H1f: Free cash flow is positively related to the BIST financial firms' dividend policy.

H1g: Liquidity is positively related to the BIST financial firms' dividend policy.

H1h: Asset tangibility is negatively related to the BIST financial firms' dividend policy.

Ownership structure. Dividend payments may be a useful tool to reduce agency problems (Easterbrook, 1984; Jensen, 1986) and signal insider information (Bhattacharya, 1979; John and Williams, 1985) in a widely held firm, where the ownership structure is dispersed among small shareholders but the corporate control remains concentrated in the hands of professional managers. However, Jensen and Meckling (1976) and Rozeff (1982) suggest that managerial (insider) stock ownership decreases the role of dividends by aligning the interests of a firm's management with its shareholders. Indeed, the empirical research has well documented a negative relation between managerial ownership and dividend policy (i.e., Lloyd et al., 1985; Jensen et al., 1992; Moh'd et al., 1995; Short et al., 2002). Examining the data from US financials, Collins et al. (1996), Dutta (1999), and Dickens et al. (2003) show that banks and insurance companies with a higher percentage of managerial ownership pay lower dividends, whereas Abreu and Gulamhussen (2013) find that US banks that are difficult to be monitored increase their dividend payments. This highlights the importance of the impact of ownership structure on dividend policy.

In this context, many renowned cross-country studies (i.e., Shleifer and Vishny, 1997; La Porta et al.1999; Claessens et al., 2000; Faccio et al., 2001), reveal that relatively few firms have dispersed ownership structures in most developing countries. Instead publicly listed firms are generally dominated and controlled by families and the state with the existence of other large shareholders, such as foreign and institutional (financial) investors in these economies. This implies that different types of stock ownership may have different effects on a firm's dividend payment decisions. For instance, La Porta et al. (1999) contend that founding families and their direct involvement in the managements of their firms lead to greater supervision and few owner-manager conflicts. According 
to Grossman and Hart (1980), Demsetz and Lehn (1985), Shleifer and Vishny (1986) and Glen et al. (1995), foreign and institutional investors with larger shareholdings have the expertise and incentive to scrutinize the firm's management, which can alleviate the free-rider problem of monitoring managers. Therefore, the highly concentrated ownership structures and close owner-manager-shareholder relations may possibly lead to fewer agency conflicts and lower levels of information asymmetries. This in turn mitigates the need for paying cash dividends as an internal disciplinary device or to signal favorable insider information.

Nevertheless, various studies (for example, Johnson et al., 2000; Anderson and Reeb, 2003; Mork and Yeung, 2003; Villalonga and Amit, 2006) argue that when large shareholders (especially families) hold almost full control, they may attempt to generate benefits to themselves at the expense of minority shareholders due to the absence of efficient monitoring on them. If this is the case, consistent with the substitute model of dividends, by paying dividends, controlling shareholders return profits to investors, which reduce the possibility of wealth transfer from others and hence establishes good treatment of minority shareholders (La Porta et al., 2000). Moreover, it is disputed that foreign investors have information disadvantages in trading local markets and the task of monitoring managements in emerging markets could be more difficult and costly for them, due to geological, cultural and political differences. Hence, they prefer higher dividends for increasing dividend-induced capital market monitoring, which suggests a positive influence of foreign investors on dividend policy (Manos, 2002; Jeon et al., 2011). Similarly, Zeckhauser and Pound (1990) state that institutional shareholders are not likely to involve direct monitoring themselves, instead they force firms to distribute dividends to augment better monitoring by capital markets. Short et al. (2002), Farinha (2003), Khan (2006) and Abdelsalam et al. (2008) indeed report a positive relationship between institutions and dividend payouts.

Gugler (2003) asserts that state-controlled firms are more likely to contain "a double owner-manager problem" and dividend payments can reduce more severe agency problems in these firms. Wang et al. (2011) and Lam et al. (2012) show that higher state ownership is associated with higher dividend payouts. In contrast, Kouki and Guizani (2009) find a negative correlation between state ownership and dividend policy. Furthermore, the presence of a large number of outside small (minority) shareholders leads to a lower level of concentration in ownerships, in other words, ownership dispersion, which increases the free-rider problem and information asymmetry. Thus, Rozeff (1982) and La Porta et al. (2000) suggest that minority investors would typically opt for higher dividends to reduce what is left for expropriation. Many researchers (i.e., Schooley and Barney, 1994; Moh'd et al., 1995; Farinha, 2003) detect a positive relation between ownership dispersion and dividend payments. Alternatively, it is argued that small investors characteristically care about the appreciation or depreciation of shares they hold and rely on capital gains rather than dividend income, due to reasons such as their incapability of monitoring the managements or favourable capital gains tax over dividends (Wei et al., 2004; Wang et al., 2011). For example, Lam et al. (2012) report that firms with higher minority ownership tend to distribute lower dividends in China. 
In short, there is a large body of literature examining the link between various types of shareholders and dividends, which confirms a solid impact of ownership structure on dividend policy. However, the extant research generally provides contradictory results regarding this impact. In a very recent study, Al-Najjar and Kilincarslan (2016) investigate the effects of family ownership, non-family blockholders (foreign investors, domestic financial institutions and the state) and minority shareholders on the dividend decisions of listed firms (excluding financials and utilities) in Turkey. They find that foreign and state ownerships are associated with the less likelihood of paying dividends, whereas all types of stock ownerships, even minority owners, have a negative influence on dividend pay ratio and dividend yield. Given that the empirical evidence is mixed, the following hypotheses are developed based on the findings of Al-Najjar and Kilincarslan (2016) in the Turkish market.

H2a: Family ownership is negatively related to the BIST financial firms' dividend policy.

H2b: Foreign ownership is negatively related to the BIST financial firms' dividend policy.

H2c: Domestic institutional ownership is negatively related to the BIST financial firms' dividend policy.

H2d: State ownership is negatively related to the BIST financial firms' dividend policy.

H2e: Minority shareholder ownership is negatively related to the BIST financial firms' dividend policy.

Board structure. The corporate governance literature suggests that boards of directors have an important role in monitoring and disciplining executive management (Fama and Jensen, 1983). From the agency cost theory perspective, this infers that dividends and boards of directors are substitutes in mitigating agency problems. Hence, this study considers the effect of board structure, such as board size, family directors and independent directors, on dividend policy of financial firms listed on the BIST.

Fiegener et al. (2000) and Gabrielsson (2007) argue that larger boards possess greater expertise and diversity of specialisation, and therefore can offer efficient monitoring, which reduces the monitoring role of dividend payments. Conversely, Jensen (1993) claims that it is more difficult to coordinate between large groups of directors but if a board is appropriately small with a sufficient number of independent directors, it provides more effective monitoring than larger boards. However, Abdelsalam et al. (2008) and Setia-Atmaja et al. (2009) find no significant impact of board size on dividend payouts. Furthermore, board representation by family members (in other words, family directors) is another common way in which owner families exercise control - in fact, the top executive is usually a family member in family-owned firms (La Porta et al., 1999; Faccio et al, 2001). Family directors on the boards generally increase the internal control 
and scrutiny (Yoshikawa and Rasheed, 2010) but may also decrease the effectiveness of the board of directors by executing policies that benefit themselves (La Porta et al., 1999). Regarding these two board characteristics, Al-Najjar and Kilincarslan (2016) report that board size has a positive effect on the dividend payment decisions (both for the decision to pay dividends and the amount of payouts), and family directors have a negative impact only on the dividend payout ratios of industrial firms in Turkey. Based on their results, the current study also predicts a significant positive relationship between board size and dividend policies of financial firms that are traded on the BIST, whereas it postulates a negative association between family directors and dividend decisions.

Moreover, it is generally suggested that independent directors improve the feasibility of the board by increasing the monitoring on controlling executive directors' actions, and independent directors are in a better position to protect outside shareholders' interests due to their independence from corporate management (Fama, 1980; Schellenger et al., 1989; Bathala and Rao, 1995). The logic is that if independent directors are effective in monitoring, then board independence will diminish the need for higher dividend payouts, but when the monitoring of independent directors are insufficient, they encourage firms to distribute higher dividends to increase dividend-induced capital market monitoring. Several studies investigate the relation between independent directors on the board and dividend policy, but the evidence is mixed. For example, Bathala and Rao (1995) and Al-Najjar and Hussainey (2009) find a negative effect of independent directors on dividends, while Schellenger et al. (1989) and Setia-Atmaja et al, (2009) detect a positive one; however, Abdelsalam et al. (2008) find no significant correlation between independent directors and dividend policy. Given the mixed results from previous research, no directional sign is predicted but this study conjectures that there is a significant relationship between independent directors on boards and dividends. Therefore:

H3a: Board size is positively related to the BIST financial firms' dividend policy.

H3b: Family directors on boards are negatively related to the BIST financial firms' dividend policy.

H3c: Independent directors on boards are related (negative or positive) to the BIST financial firms' dividend policy.

\section{Data and Methodology}

\section{Data Sample}

As of February, 1, 2017, the study identifies 80 financial firms that were listed on the BIST-Financials Index, using the Public Disclosure Platform (KAP) of Borsa Istanbul (2017). An empirical analysis then considers all of these 80 financial institutions and derives the data from several sources - particularly, information on accounting and financial variables is obtained from S\&P CAPITAL IQ database, whereas the data on 
firms' ownership, corporate governance and incorporation dates are compiled from the annual reports published in the Public Disclosure Platform of BIST and companies' official websites. Finally, the study sample covers a panel dataset of 619 firm-year observations representing 80 unique BIST financial firms from five different financial sectors (i.e., 31 holding and investment companies, 27 real estate investment trusts, 13 banks and special finance corporations, five insurance companies, and four leasing and factoring companies) between 2009 and 2016. ${ }^{[2]}$ The list of the financial firms included in the sample (with the sectors in which they operate) is given in Appendix 1.

\section{Research Design, Models and Variables}

In identifying the most important determinants affecting dividend policies of the BIST financial firms, the study constructs the research variables and models for its multivariate analysis as follows. First, it employs two different dependent variables and formulates two corresponding models. Particularly, (i) a logit model (Model 1) for the probability of paying dividends - because while setting their dividend policies, firms face two options; to pay or not to pay dividends, and thus a logit regression model is an appropriate econometric technique for estimating a binary dependent variable $(0 / 1)$, and (ii) a tobit model (Model 2) for the intensity of paying dividends that is measured by dividend payout ratio - in this case, a tobit model is suitable because dividend payout ratio will never be negative (left censored at zero), and has two outcomes; either zero (discrete numbers) when firms do not pay dividends, or a positive value (continuous numbers) if firms pay dividends. Second, it defines a set of explanatory variables, which are based on financial characteristics, ownership and board structures, and are observed in the related literature, to test the research hypotheses. Third, given that the sampled firms represent a broad cross-section of five financial sectors, the study attempts to control for the sector-specific effects by adding five sector dummies. This is because each financial sector might be governed by different regulations and follow arguably different capital structures and investment policies. In addition, it also includes year dummies into the models to account for unobserved time-varying factors. Finally, it further considers the issue of endogeneity and uses one-year lagged values of all independent variables in the models, to ensure that financial characteristics, ownership and board structures are predetermined with respect to the dividend policy decisions, and hence mitigate endogeneity problems. Accordingly, the corresponding logit model (Model 1) and tobit model (Model 2) are constructed as below:

[2] It is worth noting that since several firms in the sample were listed in different years after 2009, the panel dataset is not the same for each year during the study period from 2009 to 2016 . Therefore, it is an "unbalanced" panel data. However, the methods used in this study can be used with both a balanced and an unbalanced panel dataset. 
Model 1:

$$
\begin{aligned}
& \text { DPAY }_{i, t}= \alpha_{0}+\alpha_{1} \mathrm{ROA}_{i, t-1}+\alpha_{2} \mathrm{DEBT}_{i, t-1}+\alpha_{3} \mathrm{GROW}_{i, t-1}+\alpha_{4} \mathrm{SIZE}_{i, t-1}+ \\
& \alpha_{5} \mathrm{AGE}_{i, t-1}+\alpha_{6} \mathrm{FCF}_{i, t-1}+\alpha_{7} \mathrm{LIQ}_{i, t-1}+\alpha_{8} \mathrm{TANG}_{i, t-1}+ \\
& \alpha_{9} \mathrm{FAMILY}_{i, t-1}+\alpha_{10} \mathrm{FOREIGN}_{i, t-1}+\alpha_{11} \mathrm{INST}_{i, t-1}+ \\
& \alpha_{12} \mathrm{STATE}_{i, t-1}+\alpha_{13} \mathrm{DISP}_{i, t-1}+\alpha_{14} \mathrm{BOARD}_{i, t-1}+\alpha_{15} \mathrm{FDIR}_{i, t-1}+ \\
& \alpha_{16} \mathrm{IDIR}_{i, t-1}+\sum_{j=1}^{N} \alpha_{j} \mathrm{SECTOR}_{j, i, t}+\sum_{t=1}^{T} \alpha_{t} \mathrm{YEAR}_{i, t}+\varepsilon \\
& \operatorname{DPAY}_{i, t}=\left\{\begin{aligned}
0 \quad & \text { if } \operatorname{DPAY}_{i, t}=0, \\
1 & \text { if } \operatorname{DPAY}_{i t}>0,
\end{aligned}\right.
\end{aligned}
$$

and

Model 2:

$$
\begin{aligned}
& \text { POUT }_{i, t}= \beta_{0}+\beta_{1} \mathrm{ROA}_{i, t-1}+\beta_{2} \mathrm{DEBT}_{i, t-1}+\beta_{3} \mathrm{GROW}_{i, t-1}+\beta_{4} \mathrm{SIZE}_{i, t-1}+ \\
& \beta_{5} \mathrm{AGE}_{i, t-1}+\beta_{6} \mathrm{FCF}_{i, t-1}+\beta_{7} \mathrm{LIQ}_{i, t-1}+\beta_{8} \mathrm{TANG}_{i, t-1}+ \\
& \beta_{9} \mathrm{FAMILY}_{i, t-1}+\beta_{10} \mathrm{FOREIGN}_{i, t-1}+\beta_{11} \mathrm{INST}_{i, t-1}+ \\
& \beta_{12} \mathrm{STATE}_{i, t-1}+\beta_{13} \mathrm{DISP}_{i, t-1}+\beta_{14} \mathrm{BOARD}_{i, t-1}+\beta_{15} \mathrm{FDIR}_{i, t-1}+ \\
& \beta_{16} \mathrm{IDIR}_{i, t-1}+\sum_{j=1}^{N} \beta_{j} \mathrm{SECTOR}_{j, i, t}+\sum_{t=1}^{T} \beta_{t} \mathrm{YEAR}_{i, t}+\mathrm{u} \\
& \operatorname{POUT}_{i, t}=\left\{\begin{aligned}
0 & \text { if } \operatorname{POUT}_{i, t}=0, \\
\text { POUT }_{i, t} & \text { if } \operatorname{POUT}_{i, t}>0,
\end{aligned}\right.
\end{aligned}
$$

where DPAY is the probability of paying a cash dividend, which is a binary code that equals 1 if the firm pays dividends and 0 otherwise (Model 1), and POUT represents the dividend payout ratio that is the fraction of dividends per share to earnings per share (Model 2) in a given year over the period 2009-2016. The explanatory (test) variables are as follows: profitability (ROA); debt (DEBT); the market-to-book ratio for growth/ investment opportunities (GROW); firm size (SIZE); firm age (AGE); free cash flow (FCF); liquidity (LIQ); asset tangibility (TANG); family ownership (FAMILY); foreign ownership (FOREIGN); domestic institutional ownership (INST); state ownership (STATE); ownership dispersion (DISP); board size (BOARD); the proportions of family directors (FDIR) and independent directors (IDIR) on the boards. The control variables are as follows: SECTOR is a vector of sector dummy variables using 5 different sector classifications of the study sample (that is, SECTOR1 through SECTOR5) and YEAR represents yearly dummies for the years from 2009 to 2016, which take a value of 1 for a particular year and 0 otherwise. The definitions for all independent variables used in the models and the consistency of these variables with previous studies are provided in Appendix 2. 


\section{Empirical Results and Discussion}

\section{Descriptive Analysis}

Table 1 presents descriptive statistics for the research variables used in the multivariate tests. The panel dataset (unbalanced) includes 80 unique BIST-listed financial institutions with 619 firm-year observations over the period 2009-2016. ${ }^{[3]}$

Table 1

\section{Descriptive Statistics}

\begin{tabular}{l|c|c|c|c|c|c}
\hline Variables & $\boldsymbol{N}$ & Mean & Median & Std. Dev. & Minimum & Maximum \\
\hline DPAY & 619 & 0.446 & 0.000 & 0.497 & 0.000 & 1.000 \\
\hline POUT & 601 & 0.281 & 0.000 & 1.655 & 0.000 & 5.983 \\
\hline ROA & 619 & 0.035 & 0.021 & 0.086 & -0.969 & 0.578 \\
\hline DEBT & 619 & 0.229 & 0.195 & 0.228 & 0.000 & 0.966 \\
\hline GROW & 619 & 1.356 & 0.865 & 1.889 & 0.083 & 24.93 \\
\hline SIZE & 619 & 6.281 & 6.004 & 1.857 & 1.991 & 10.58 \\
\hline AGE & 619 & 3.024 & 3.045 & 0.946 & 0.693 & 4.522 \\
\hline FCF & 619 & -0.543 & -0.063 & 2.131 & -13.55 & 9.915 \\
\hline LIQ & 619 & 6.621 & 1.394 & 15.95 & 0.001 & 46.80 \\
\hline TANG & 619 & 0.595 & 0.702 & 0.310 & 0.000 & 0.999 \\
\hline FAMILY & 619 & 0.342 & 0.338 & 0.325 & 0.000 & 0.999 \\
\hline FOREIGN & 619 & 0.082 & 0.000 & 0.220 & 0.000 & 0.998 \\
\hline INST & 619 & 0.129 & 0.000 & 0.254 & 0.000 & 0.998 \\
\hline STATE & 619 & 0.043 & 0.000 & 0.149 & 0.000 & 0.996 \\
\hline DISP & 619 & 0.378 & 0.342 & 0.210 & 0.001 & 1.000 \\
\hline BOARD & 619 & 7.976 & 8.000 & 2.373 & 3.000 & 18.00 \\
\hline FDIR & 619 & 0.175 & 0.111 & 0.201 & 0.000 & 0.750 \\
\hline IDIR & 619 & 0.220 & 0.286 & 0.142 & 0.000 & 0.429 \\
\hline
\end{tabular}

At first glance, the mean DPAY (0.446) indicates that BIST financials paid dividends in about $45 \%$ of the total observations, whereas POUT shows that the average payout ratio is $28.1 \%$ for the entire sample. Further, the statistics of DEBT and ROA reveal that firms make about $23 \%$ debt financing in their capital structure and they had approximately $3.5 \%$ of the returns on their total assets invested over the period. On average, BIST financials had a good prospect of growth opportunities as GROW demonstrates a mean market-to-book ratio of 1.356 that is higher than unity between 2009 and 2016 .

${ }^{[3]}$ Each of the research variables has 619 firm-year observations, except the dividend payout ratio (POUT). When a firm makes losses, its earnings per share becomes negative, and even if that firm distributes a cash dividend, its dividend payout ratio will be negative - nevertheless, a firm's dividend payout ratio cannot be negative. Hence, such observations are excluded and this in turn leads to 601 firm-year observations for POUT. 


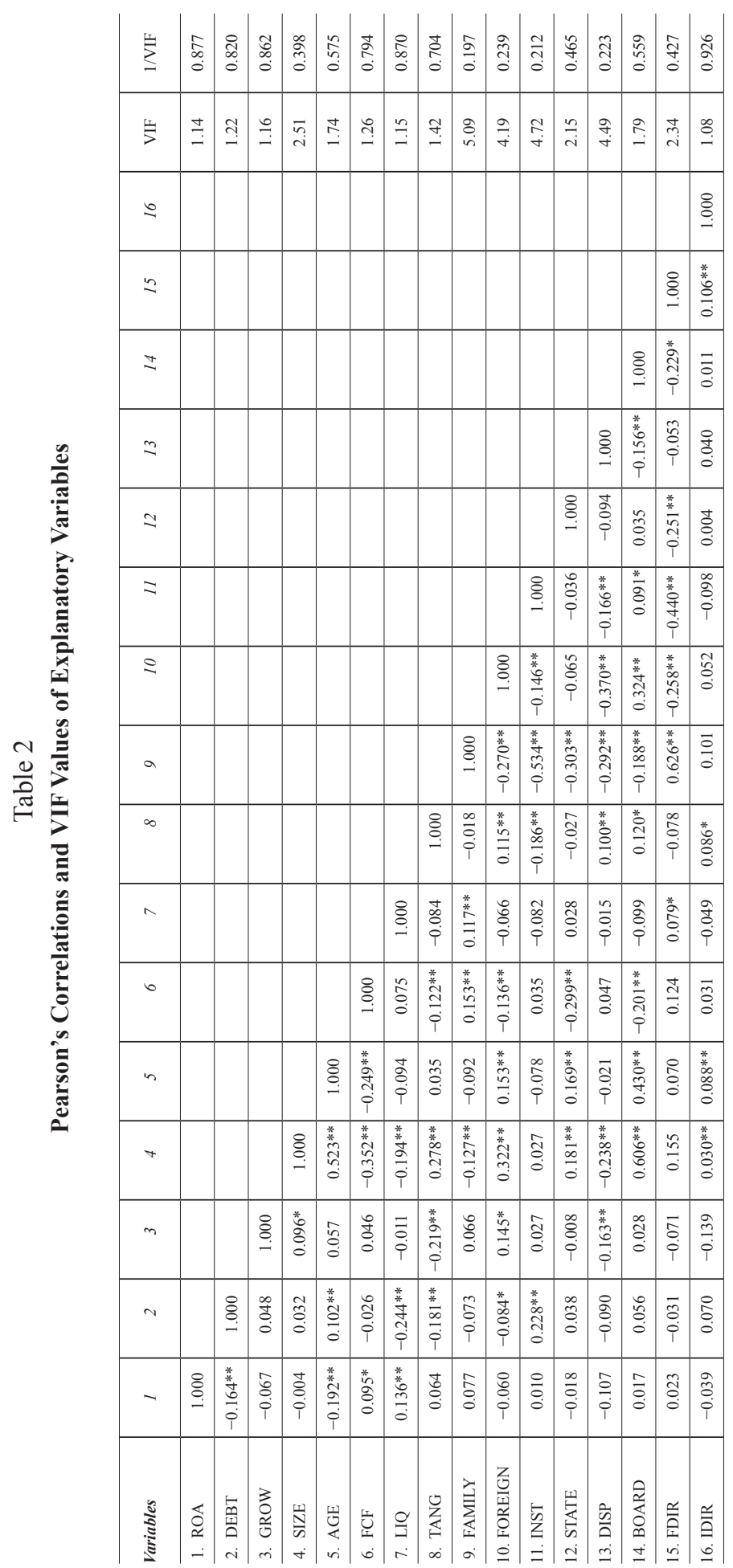


As well, the negative mean free cash flow per share (FCF) signifies the higher growing (investment) prospects of the sampled firms - this may also imply potential problems such as cash shortages and poor debt structures. LIQ displays a high average current ratio of around 6.6:1, which suggests that BIST financials are generally capable of paying their obligations. In addition, the mean TANG of 0.595 reveals that firms in the sample have, on average, almost $60 \%$ of their assets as fixed (tangible) assets. Moreover, BIST financial corporations show highly concentrated ownership structures, mostly dominated by families $(34.2 \%)$ followed by Turkish financial institutions $(12.9 \%)$. Other large shareholders, such as foreign investors own around $8 \%$ and the state holds about $4 \%$ over the research period, whereas minority shareholders have almost $38 \%$ of the outstanding shares of the BIST-listed financial firms. It is also observed that the proportions of independent directors and family members on the boards (which are generally sized of eight directors) are, on average, $22 \%$ and $17.5 \%$, respectively.

Table 2 above displays the results of Pearson's correlation and Variance Inflation Factor (VIF) values for the explanatory variables. The results show significant correlations amongst the research variables. However, no high correlation exists between any two of them, although a few of variables are moderately correlated. In addition, the VIF and tolerance (calculated as 1/VIF) statistics are further estimated to check whether multicollinearity exists between explanatory variables. As a rule of thumb, a VIF greater than 10 and a tolerance value lower than 0.1 (that corresponds to a VIF value of 10) indicate multicollinearity. Given that none of the VIFs exceeds 10 and none of the tolerance values are smaller than 0.1 , the results suggest no multicollinearity problem exists between the explanatory variables.

\section{Regression Analysis}

Table 3 reports the results of the logit and tobit regressions - particularly, Model 1 shows the random effects logit estimates on the probability of paying a cash dividend, whereas Model 2 presents the random effect tobit estimates on the dividend payout ratio. The table also illustrates the marginal effects (economic significance) of the explanatory variables to provide further interpretations in addition to the logit/tobit coefficient estimates (statistical significance) - it is worth noting that the marginal effects reflect the marginal impact of each of the explanatory variables on the dependent variable at the mean values of other explanatory variables.

The results reveal that Model 1 and Model 2 are overall statistically significant at the $1 \%$ level, as evidenced by the Wald $\chi^{2}$ tests. Further, the likelihood-ratio tests are highly significant at the $1 \%$ level, indicating that the panel-level variance component $(\rho)$ values are considerably different from zero for Model 1 and Model 2 (0.598 and 0.307, respectively). This finding suggests that the random effects (panel) model estimates are more favourable than the pooled model estimates in predicting the associations between firm characteristics and dividend policy decisions of the BIST financials. ${ }^{[4]}$

[4] Using the pooled logit and pooled tobit regressions to estimate Model 1 and Model 2, respectively, obtains similar results. Since the likelihood-ratio tests show that the random effects (panel) models are more favourable than the pooled models, the study reports the results based the random effects logit/tobit estimates. 
Table 3

\section{Results of Regression Estimates on Dividend Policy}

\begin{tabular}{|c|c|c|c|c|}
\hline \multirow{3}{*}{$\begin{array}{l}\text { Dependent variable: } \\
\text { Model: } \\
\text { Independent variables: }\end{array}$} & \multicolumn{2}{|c|}{$\operatorname{DPAY}_{i, t}(0 / 1)$} & \multicolumn{2}{|c|}{$\mathrm{POUT}_{i, t}$} \\
\hline & \multicolumn{2}{|c|}{ Model 1: Random Effects Logit } & \multicolumn{2}{|c|}{ Model 2: Random Effects Tobit } \\
\hline & $\begin{array}{c}\text { Coefficient } \\
\text { estimates }\end{array}$ & $\begin{array}{c}\text { Marginal } \\
\text { effects }\end{array}$ & $\begin{array}{c}\text { Coefficient } \\
\text { estimates }\end{array}$ & $\begin{array}{c}\text { Marginal } \\
\text { effects }\end{array}$ \\
\hline \multicolumn{5}{|l|}{ Financial characteristics: } \\
\hline $\mathrm{ROA}_{i, t_{-l}}$ & $\begin{array}{c}0.867 * * \\
(2.28)\end{array}$ & $\begin{array}{c}0.090^{* *} \\
(2.35)\end{array}$ & $\begin{array}{c}1.388 * * * \\
(3.60)\end{array}$ & $\begin{array}{c}0.130 * * * \\
(3.64)\end{array}$ \\
\hline $\operatorname{DEBT}_{i, t{ }_{l}}$ & $\begin{array}{c}-5.110^{* * * *} \\
(-3.33)\end{array}$ & $\begin{array}{c}-0.599 * * * \\
(-3.65)\end{array}$ & $\begin{array}{c}-3.739 * * * \\
(-2.84)\end{array}$ & $\begin{array}{c}-0.359^{* * *} \\
(-2.98)\end{array}$ \\
\hline $\operatorname{GROW}_{i, t_{-1}}$ & $\begin{array}{c}-0.434 * \\
(-1.72)\end{array}$ & $\begin{array}{c}-0.046^{*} \\
(-1.77)\end{array}$ & $\begin{array}{c}-1.526^{*} \\
(-1.92)\end{array}$ & $\begin{array}{c}-0.043^{*} \\
(-1.95)\end{array}$ \\
\hline $\operatorname{SIZE}_{i, t_{-1}}$ & $\begin{array}{c}1.515^{* * *} \\
(6.03)\end{array}$ & $\begin{array}{c}0.171 * * * \\
(8.92)\end{array}$ & $\begin{array}{c}1.827 * * * \\
(5.21)\end{array}$ & $\begin{array}{c}0.089 * * * \\
(5.97)\end{array}$ \\
\hline $\mathrm{AGE}_{i, t-{ }_{l}}$ & $\begin{array}{l}0.370 \\
(1.25)\end{array}$ & $\begin{array}{l}0.021 \\
(1.25)\end{array}$ & $\begin{array}{l}1.089 \\
(1.34)\end{array}$ & $\begin{array}{l}0.018 \\
(1.34)\end{array}$ \\
\hline $\mathrm{FCF}_{i, t_{-I}}$ & $\begin{array}{l}0.067 \\
(0.49)\end{array}$ & $\begin{array}{l}0.007 \\
(0.50)\end{array}$ & $\begin{array}{l}0.376 \\
(0.62)\end{array}$ & $\begin{array}{l}0.004 \\
(0.64)\end{array}$ \\
\hline $\mathrm{LIQ}_{i, t_{-1}}$ & $\begin{array}{l}0.015 \\
(0.34)\end{array}$ & $\begin{array}{l}0.001 \\
(0.33)\end{array}$ & $\begin{array}{c}1.462 * * * \\
(3.74)\end{array}$ & $\begin{array}{c}0.036^{* * * *} \\
(3.82)\end{array}$ \\
\hline TANG $_{i, t-}{ }_{l}$ & $\begin{array}{l}-1.734 \\
(-1.50)\end{array}$ & $\begin{array}{l}-0.172 \\
(-1.51)\end{array}$ & $\begin{array}{c}-4.241 * * * \\
(-3.19)\end{array}$ & $\begin{array}{c}-0.271^{* * *} \\
(-3.25)\end{array}$ \\
\hline
\end{tabular}

Ownership structure:

\begin{tabular}{lc|cc|c} 
FAMILY $_{i, t_{-1}}$ & -0.028 & -0.006 & -0.884 & -0.005 \\
& $(-0.76)$ & $(-0.77)$ & $(-1.19)$ & $(-1.17)$ \\
FOREIGN $_{i, t-}$, & $-0.129 * *$ & $-0.015^{* *}$ & $-1.099^{* * *}$ & $-0.028^{* * *}$ \\
& $(-2.30)$ & $(-2.42)$ & $(-3.26)$ & $(-3.37)$ \\
INST $_{i, t_{-l}}$ & -0.028 & -0.003 & -0.430 & -0.003 \\
STATE $_{i, t-}$, & $(-0.53)$ & $(-0.53)$ & $(-0.94)$ & $(-0.95)$ \\
& -0.057 & -0.006 & -0.136 & -0.005 \\
DISP $_{i, t_{-1}}$ & $(-1.36)$ & $(-1.38)$ & $(-1.53)$ & $(-1.55)$ \\
& -0.041 & -0.005 & -0.078 & -0.003 \\
& $(-1.03)$ & $(-1.03)$ & $(-0.96)$ & $(-0.96)$
\end{tabular}

Board structure:

\begin{tabular}{cc|cc|c} 
BOARD $_{i, t-}$, & 0.085 & 0.010 & $3.931^{* *}$ & $0.035^{* *}$ \\
& $(-0.69)$ & $(-0.70)$ & $(2.44)$ & $(-2.46)$ \\
FDIR $_{i, t_{-1}}$ & -1.180 & -0.144 & $-4.693^{* * *}$ & $-0.153^{* * *}$ \\
IDIR $_{i, t-}$, & $(-1.13)$ & $(-1.15)$ & $(-3.29)$ & $(-3.81)$ \\
& $0.461^{*}$ & $0.043^{*}$ & 0.176 & 0.012 \\
& $(1.69)$ & $(1.80)$ & $(1.08)$ & $(1.10)$ \\
SECTOR1 & & & & \\
& 1.023 & 0.120 & 1.983 & 0.128 \\
Sector dummies: & $(0.74)$ & $(0.72)$ & $(1.26)$ & $(1.30)$
\end{tabular}


Table 3 (continued)

\begin{tabular}{|c|c|c|c|c|}
\hline \multirow{3}{*}{$\begin{array}{l}\text { Dependent variable: } \\
\text { Model: } \\
\text { Independent variables: }\end{array}$} & \multicolumn{2}{|c|}{$\operatorname{DPAY}_{i, t}(0 / 1)$} & \multicolumn{2}{|c|}{$\operatorname{POUT}_{i, t}$} \\
\hline & \multicolumn{2}{|c|}{ Model 1: Random Effects Logit } & \multicolumn{2}{|c|}{ Model 2: Random Effects Tobit } \\
\hline & $\begin{array}{c}\text { Coefficient } \\
\text { estimates }\end{array}$ & $\begin{array}{l}\text { Marginal } \\
\text { effects }\end{array}$ & $\begin{array}{c}\text { Coefficient } \\
\text { estimates }\end{array}$ & $\begin{array}{c}\text { Marginal } \\
\text { effects }\end{array}$ \\
\hline SECTOR2 & $\begin{array}{l}0.345 \\
(0.42)\end{array}$ & $\begin{array}{l}0.033 \\
(0.42)\end{array}$ & $\begin{array}{l}0.678 \\
(1.05)\end{array}$ & $\begin{array}{l}0.036 \\
(1.05)\end{array}$ \\
\hline SECTOR3 & $\begin{array}{l}0.363 \\
(0.22)\end{array}$ & $\begin{array}{l}0.028 \\
(0.22)\end{array}$ & $\begin{array}{l}0.450 \\
(0.36)\end{array}$ & $\begin{array}{l}0.022 \\
(0.36)\end{array}$ \\
\hline SECTOR4 & $\begin{array}{l}1.295 \\
(1.40)\end{array}$ & $\begin{array}{l}0.317 \\
(1.43)\end{array}$ & $\begin{array}{l}1.432 \\
(0.89)\end{array}$ & $\begin{array}{l}0.416 \\
(0.96)\end{array}$ \\
\hline SECTOR5 & $\begin{array}{l}0.656 \\
(0.83)\end{array}$ & $\begin{array}{l}0.196 \\
(0.84)\end{array}$ & $\begin{array}{l}0.509 \\
(0.53)\end{array}$ & $\begin{array}{l}0.147 \\
(0.53)\end{array}$ \\
\hline YEAR & Yes & Yes & Yes & Yes \\
\hline Constant & $\begin{array}{l}-5.818 \\
(-1.09)\end{array}$ & & $\begin{array}{l}-7.139 \\
(-1.21)\end{array}$ & \\
\hline Number of observations & 539 & 539 & 521 & 521 \\
\hline Wald $\chi^{2}$ & $67.71 * * *$ & & $89.78 * * *$ & \\
\hline$\rho$ value & 0.598 & & 0.307 & \\
\hline Likelihood ratio test & $72.19 * * *$ & & $48.39 * * *$ & \\
\hline
\end{tabular}

Notes: The table reports the logit/tobit estimates and z statistics in the parentheses. $* * *, * *$ and $*$ stand for significance at the $1 \%, 5 \%$ and $10 \%$ levels, respectively. Independent variables are one-year lagged.

Regarding financial characteristics, the empirical results reveal the following findings. The random effects logit and tobit estimates show that the coefficients on ROA (profitability) are positive and statistically significant $(z=2.28, p<0.05$ in Model 1 and $z=3.60, p<0.01$ in Model 2). The marginal effects of this variable indicate, other things being equal, that a 10 percentage point increase in ROA will approximately result in a 0.9 percentage point increase in the probability of paying dividends, and a 1.3 percentage point increase in the level of dividend payout ratio. This evidence of a positive relationship between profitability and dividend policy is in line with the extant studies (i.e., Fama and French, 2001; Aivazian et al., 2003; Ferris et al., 2006) and suggests that more profitable BIST financial firms are more likely to pay dividends to show their better financial performance, consistent with the signalling theory. Therefore, this lends support for Hla. Nevertheless, the results in Table 3 detect a strong negative influence of debt level (DEBT) on dividends, since the coefficients on DEBT are negative and highly significant in both models $(z=-3.33, p<0.01$ in Model 1 and $z=-2.84, p<$ 0.01 in Model 2). The marginal effects imply that the probability of distributing a cash dividend drops by around 6 percentage point and the dividend payout ratio decreases by about 3.6 percentage point for an average firm, corresponding to a 10 percentage point increase in DEBT. This negative impact is supported by previous studies, such as Aivaizan et al. (2003), Al-Najjar (2009) and Kirkulak and Kurt (2010) and reflects the transaction costs of external financing as well as the substitution roles of debt and dividends in controlling agency problems (Rozeff, 1982; Jensen, 1986; Manos, 2002). 
Accordingly, BIST financials with higher debt levels tend to pay none or lower dividends. Thus, this leads to accept $H 1 b$.

Moreover, the results reveal another negative correlation that is between growth opportunities (GROW) and dividend payment decisions. The coefficients on GROW are significantly negative in logit and tobit models $(z=-1.72, p<0.10$ in Model 1 and $z$ $=-1.92, p<0.10$ ) and the marginal effects of the variable signify, all else being equal, that a 10 percentage point increase in the growth opportunities will decrease both the probability of paying dividends and the dividend payout ratio by roughly 0.45 percentage point. This means that high-growth BIST financial firms are more likely to use their earnings to finance their investments rather than paying dividends, consistent with the pecking order theory (Myers, 1984; Myers and Majluf, 1984) and prior research (i.e., Rozeff, 1982; Fama and French, 2001; Baker and Wurgler, 2004; Ferris et al., 2006). Hence, this provides support for H1c. Conversely, corporate dividend decisions of BIST financials are found to be positively affected by firm size (SIZE), as the coefficients on SIZE are positive and highly significant in both models $(z=6.03, p<0.01$ in Model 1 and $z=5.21, p<0.01$ in Model 2). The marginal effects show that a 10 percentage point increase in firm size will approximately lead to a 1.7 percentage point increase in the probability of distributing a cash dividend, and a 0.9 percentage point increase in dividend payout ratio for an average firm. This positive impact reflects the concept that larger firms face lower transaction costs and higher potential for agency problems, and thus they distribute higher dividends as a controlling device (Lloyd et al., 1985; Moh'd et al., 1995; Fama and French, 2001; Ferris et al., 2006). Therefore, this leads to accept H1d.

Although the random effects logit estimates (Model 1) find no significant effects of firm liquidity (LIQ) and asset tangibility (TANG) on the probability of paying dividends, the random effects tobit estimates (Model 2) reveal that both factors have important implications on the dividend payout ratio. More specifically, the tobit coefficients on LIQ and TANG are highly significant, but indicate a positive sign for the first and a negative one for the latter ( $z=3.74, p<0.01$ and $z=-3.19, p<0.01$, respectively). The marginal effects of these variables indicate that a 10 percentage point increase in LIQ and TANG will approximately have a 0.36 percentage point increase and a 2.7 percentage point decrease in dividend payout ratio, respectively. This implies that firm liquidity and asset tangibility do not affect BIST financial firms' decisions about whether or not to pay dividends. However, once they decide to pay, liquidity encourages them to distribute higher dividends, whereas assets tangibility pushes them to pay lower dividends. As hypothesised, this suggests that high-liquidity BIST financials signal their better liquidity positions (Ho, 2003), in line with the signalling theory. On the other hand, larger fractions of long-term tangible assets reduce the borrowing capacity of BIST financials, which in turn forces them to make more use of internal funds while decreasing the amounts of dividend payouts (Aivazian et al., 2003; Ho, 2003; Al-Najjar, 2009). Hence, these findings provide partial support for $H 1 \mathrm{~g}$ and $H 1 \mathrm{~h}$.

Furthermore, the random effects logit and tobit regressions results from Model 1 and Model 2 show no significant association between firm age (AGE) and free cash flow 
per share (FCF), and corporate dividend payment decisions of BIST financial firms at any conventional significance levels. The evidence of an insignificant relationship between firm age and dividends is contradictory to the maturity hypothesis that suggests that firm age is an important factor affecting divided policy and more mature firms are more likely to pay higher dividends (Grullon et al., 2002; DeAngelo et al., 2006). This is probably due to the fact that the financial sector in Turkey is still at the growing stage, small and shallow as compared to the financial sectors in developed countries (BAT, 2009). Also, Jensen (1986) argues that large dividend payments are a useful tool to alleviate agency costs when firms have extensive amounts of free cash flow under managers' control. However, as illustrated in the descriptive analysis, BIST financials have, on average, negative free cash flows, which is thought to be the reason for the insignificant association between free cash flow and dividends. Therefore, these results lead to the rejection of Hle and HIf.

In order to identify how ownership structure affects dividend decisions of BIST financial firms, five ownership effect variables are created, namely family ownership (FAMILY), foreign ownership (FOREIGN), domestic institutional ownership (INST), state ownership (STATE), and minority shareholder ownership (DISP). The empirical results in Table 3 present that all of the ownership variables are negatively related to both the probability of paying dividends and dividend payouts. Even though this negative relationship is consistent with the evidence provided by Al-Najjar and Kilincarslan (2016), who examine non-financial corporations in Turkey, it is, however, found to be statistically significant for only foreign ownership. Indeed, the random effects logit and tobit estimates report that the coefficients on FOREIGN are negative and highly significant $(z=-2.30, p<0.05$ in Model 1 and $z=-3.26, p<0.01$ in Model 2). The marginal effects of the variable show that a 10 percentage point increase in FOREIGN will approximately result in a 0.15 percentage point decrease in the probability of distributing dividends and a 0.28 percentage point drop in the dividend payout ratio for an average firm. This means that higher foreign ownership leads to none or lower dividend payments, which may suggest that foreign investors invest in stocks of BIST financials for their long-run growth potential, rather than the short-term dividend income. The evidence might also imply that foreign blockholders have the expertise and incentive to monitor corporate managers and thus their existence reduces the need for paying cash dividends as an internal disciplinary device (Grossman and Hart, 1980; Demsetz and Lehn, 1985; Glen et al., 1995). Consequently, considering the significantly negative impact of foreign ownership and given the non-significant effects of all other ownership variables, these findings provide support for $H 2 b$ but lead to the rejection of $H 2 a$, $H 2 c, H 2 d$ and $H 2 e$.

With respect to the board structure variables, the random effects logit estimates show that the proportion of independent directors on the board (IDIR) positively and significantly affects the BIST financials' decisions on whether to pay dividends $(z=$ $1.69, p<0.10)$, whereas board size (BOARD) and the proportion of family members on the board (FDIR) have no impact at any conventional significance levels in Model 1. The marginal effect of IDIR indicates that one unit of increase in this variable will 
increase the probability of paying dividends by about $4.3 \%$. This positive impact is consistent with Schellenger et al. (1989) and Setia-Atmaja et al. (2009), and suggests that independent directors encourage BIST financials to pay dividends to increase the dividend-induced capital market monitoring. However, the random effects tobit estimates reveal that board size and the proportion of family directors on the board are significant factors determining the level of dividend payout ratio - the tobit coefficients report a positive sign for the first one and a negative one for the latter $(z=2.44, p<0.05$ and $z$ $=-3.29, p<0.01$, respectively), but independent directors have no significant effect in Model 2. The marginal effects of BOARD and FDIR infer that one unit of increase in BOARD and FDIR will roughly have an increase of $3.5 \%$ and a decrease of $15.3 \%$ in the level of dividend payout ratio, respectively. This evidence is in line with Al-Najjar and Kilincarslan (2016) who also report that board size has a positive effect and family directors have a negative influence on dividend payouts of industrial firms in Turkey. Overall, these results lend partial support for $H 3 a, H 3 b$ and $H 3 c$.

The financial services industry is subject to tighter regulations. Even different sectors within this industry may be governed by different rules due to their substantially different characteristics (i.e., different capital structures and investment policies). Given that the data sample of 80 BIST financial firms are drawn from five broad financial sectors, the study adds sector classification dummies in the models to find out whether there are any sector-specific effects on the dividend policy decisions of the BIST financial firms. In particular, SECTOR1 represents "banks and special finance corporations", SECTOR2 indicates "holding and investment companies, SECTOR3 accounts for "insurance firms", SECTOR4 represents "leasing and factoring companies" and SECTOR5 signifies "real estate investment trusts". The empirical results, however, show that none of the coefficients of these sector dummies is statistically significant in Model 1 and Model 2. Hence, this finding suggests that no considerable sector-specific effect exists among the sampled BIST financial firms.

Additionally, the study performs supplementary tests to check the robustness of the main findings. This is done by employing an alternative dependent variable, namely "dividend yield". Using dividend yield (which is a market measure that is defined as dividends per share to price per share) instead of dividend payout ratio (which is an accounting measure that is calculated as dividends per share to earnings per share) provides more evidence from a different point of view and allows to find out whether primary results are sensitive to the usage of a different dividend policy measure. Since dividend yield will have two outcomes: either zero (discrete numbers) or a positive value (continuous numbers) - as in the way of estimating dividend payout ratio, a tobit model is applied to estimate the impacts of previously defined explanatory variables on the levels of dividend yield of BIST financial firms. As illustrated in Table 4, the random effects tobit coefficients and marginal effects on dividend yield (denoted as DYIELD) in Model 3 provide very similar results to the tobit estimates on dividend payout ratio (Model 2), and therefore confirm the robustness of the previous findings. 
Table 4

\section{Results of Further Tests}

\begin{tabular}{lc|c}
\hline \multirow{2}{*}{ Dependent variable: } & \multicolumn{2}{c}{ DYIELD $_{i, t}$} \\
\hline Model: & \multicolumn{2}{c}{ Model 3: Random Effects Tobit } \\
\cline { 2 - 3 } Independent variables: & Coefficient estimates & Marginal effects \\
\hline Financial characteristics: & $0.177^{* * *}(4.85)$ & $0.115^{* * *}(4.88)$ \\
ROA $_{i, t-1}$ & $-4.934^{* * *}(-3.25)$ & $-0.328^{* * *}(-3.35)$ \\
$\mathrm{DEBT}_{i, t-1}$ & $-0.601^{* *}(-2.40)$ & $-0.034^{* *}(-2.53)$ \\
$\mathrm{GROW}_{i, t-1}$ & $1.521^{* * *}(5.06)$ & $0.109^{* * *}(6.10)$ \\
$\mathrm{SIZE}_{i, t-1}$ & $0.578(0.84)$ & $0.039(0.84)$ \\
$\mathrm{AGE}_{i, t-1}$ & $0.061(0.47)$ & $0.009(0.49)$ \\
$\mathrm{FCF}_{i, t-1}$ & $0.145^{* *}(2.47)$ & $0.055^{* *}(2.56)$ \\
$\mathrm{LIQ}_{i, t-1}$ & $-4.015^{* * *}(-3.05)$ & $-0.417^{* * *}(-3.43)$ \\
$\mathrm{TANG}_{i, t-1}$ &
\end{tabular}

Ownership structure:

\begin{tabular}{lc|c} 
FAMILY $_{i, t-1}$ & $-0.081(-1.16)$ & $-0.007(-1.16)$ \\
FOREIGN $_{i, t-1}$ & $-0.138^{* * *}(-2.63)$ & $-0.015^{* * *}(-2.75)$ \\
$\operatorname{INST}_{i, t-1}$ & $-0.115(-1.21)$ & $-0.006(-1.23)$ \\
STATE $_{i, t-1}$ & $-0.053(-0.72)$ & $-0.004(-0.74)$ \\
DISP $_{i, t-1}$ & $-0.179(-0.96)$ & $-0.013(-0.96)$ \\
\hline
\end{tabular}

Board structure:

\begin{tabular}{lc|c} 
BOARD $_{i, t-1}$ & $1.465^{* *}(2.24)$ & $0.010^{* *}(-2.29)$ \\
FDIR $_{i, t-12}$ & $-0.799^{* *}(-2.38)$ & $-0.062^{* *}(-2.44)$ \\
IDIR $_{i, t-1}$ & $0.166(0.76)$ & $0.011(0.79)$ \\
\hline
\end{tabular}

Sector dummies:

\begin{tabular}{lc|c} 
SECTOR1 & $0.292(0.75)$ & $0.022(0.77)$ \\
SECTOR2 & $0.273(1.05)$ & $0.018(1.10)$ \\
SECTOR3 & $0.325(0.94)$ & $0.026(0.94)$ \\
SECTOR4 & $0.561(0.70)$ & $0.032(0.70)$ \\
SECTOR5 & $0.289(1.17)$ & $0.020(1.09)$ \\
\hline$Y E A R$ & Yes & Yes \\
Constant & $-3.953(-0.63)$ & 539 \\
\hline Number of observations & 539 & \\
Wald $\chi^{2}$ & $93.80^{* * *}$ & \\
$\rho$ value & 0.485 & \\
Likelihood ratio test & $86.98^{* * *}$ & \\
\hline
\end{tabular}


Notes: The table reports the tobit estimates and $z$ statistics in the parentheses. $* * *, * *$ and $*$ stand for significance at the $1 \%, 5 \%$ and $10 \%$ levels, respectively. Independent variables are one-year lagged.

Model 3:

$$
\begin{aligned}
& \operatorname{DYIELD}_{i, t}=\gamma_{0}+\gamma_{t} \mathrm{ROA}_{i, t-1}+\gamma_{2} \mathrm{DEBT}_{i, t-1}+\gamma_{3} \mathrm{GROW}_{i, t-1}+\gamma_{4} \mathrm{SIZE}_{i, t-1}+\gamma_{5} \mathrm{AGE}_{i, t-1}+\gamma_{6} \mathrm{FCF}_{i, t-1}+ \\
& \gamma_{7} \mathrm{LIQ}_{i, t-1}+\gamma_{8} \mathrm{TANG}_{i, t-1}+\gamma_{g} \mathrm{FAMILY}_{i, t-1}+\gamma_{t 0} \mathrm{FOREIGN}_{i, t-1}+\gamma_{l l} \mathrm{NNST}_{i, t-1}+ \\
& \gamma_{12} \mathrm{STATE}_{i, t-1}+\gamma_{13} \mathrm{DISP}_{i, t-1}+\gamma_{14} \mathrm{BOARD}_{i, t-1}+\gamma_{15} \mathrm{FDIR}_{i, t,-1}+\gamma_{16} \mathrm{IDIR}_{i, t-1}+ \\
& \sum_{j=1}^{N} \gamma_{j} \mathrm{SECTOR}_{j, i, t}+\sum_{t=1}^{T} \gamma_{t} \mathrm{YEAR}_{i, t}+\omega \\
& \operatorname{DYIELD}_{i, t}= \begin{cases}0 & \text { if } \text { DYIELD }_{i, t}=0, \\
\text { DYIELD }_{i, t} & \text { if } \text { DYIELD }_{i t}>0,\end{cases}
\end{aligned}
$$

where DYIELD $D_{i, t}$ is the dividend yield (the ratio of dividends per share to price per share) for firm i at year $t$ between 2009 and 2016. The independent variables have the same previous definitions as given in Appendix 2.

\section{Conclusions}

Using a sample of BIST financials over the period 2009-2016, this study attempts to identify the most important firm characteristics determining the corporate dividend decisions of financial firms and to find out whether these factors are consistent with those of the non-financial firms documented in the literature. The study is important because it contributes more information about the dividend policy of financial firms to the dividend literature, which contains voluminous empirical research that has mainly focused on non-financial companies while excluding financial institutions. Further, the study presents new evidence from the emerging Turkish market that has a bank-based financial system in which the ownership of public firms is highly concentrated, unlike the most well-developed capital markets. Also, it investigates the dividend policies of financial firms of this emerging market in the period when compulsory dividend payout requirements are abolished, which provides greater flexibility in making dividend payment decisions, along with implementations of major economic and structural reforms for market integration.

The study considers various factors related to financial characteristics, ownership and board structures, and analyses the effects of these variables on dividend policy of BIST financials based on the decision to pay or not pay, and how much dividends to pay. Accordingly, the findings of this study lead to several conclusions about the dividend policy of financial firms.

First, the results show that profitability, debt, growth (investment) opportunities and firm size are the financial characteristics primarily affecting both the likelihood of paying dividends and dividend payouts of listed-financial firms - in particular, more profitable and larger-sized BIST financials are more likely to pay a cash dividend and distribute higher dividends, whereas financial firms with more debt and higher growth are less likely to pay a cash dividend and distribute lower dividends in the Turkish market. The positive effects of profitability and firm size suggests that profitable financial institutions have higher dividend payouts to signal their better financial performance, and financials large in size face lower transaction costs but higher potential for agency problems, thus they pay larger dividends as a controlling mechanism. On the other hand, the negative impacts of debt and growth imply that financial firms with higher levels of debt tend to conserve their earnings to lower the risk and the transaction costs 
of external financing, and this may also be attributed to the explanation that debt and dividends are alternative devices in controlling agency problems, hence they pay fewer dividends. Similarly, high-growth financials are more likely to retain their cash to fund their investments, which in turn leads to distribute none or low dividends.

Moreover, the results reveal that firm liquidity and asset tangibility have no influence on the BIST financial corporations' decisions to pay dividends or not; nevertheless, once they choose to pay, liquidity encourages them to pay larger dividends (a positive effect), whereas asset tangibility leads them to pay lower dividends (a negative effect). This infers that high-liquidity financial firms convey their better liquidity position (i.e., paying their obligations easily and thus involving lower risk of default) by setting high payouts. On the contrary, greater proportions of long-term tangible assets reduce the short-term borrowing capacity of financials, and hence this pushes them to make more use of internal funds while lessening the amounts of dividend payouts. However, the empirical results indicate that firm age and free cash flow are insignificant financial characteristics, which have no impact while BIST financial firms set their dividend policies. The evidence of non-significant effect of firm age may reflect the fact that BIST financial firms are relatively young and small since the financial sector in Turkey is yet at the growing stage. Besides, negative free cash flows, due to the higher growing prospects or potential problems associated with cash shortages or poor debt structures, seem to be the reason for the insignificant association between free cash flow and dividends.

Among the ownership structure variables, only foreign investor shareholdings are found to be significantly affecting the dividend policy of financial firms. In fact, the results report a negative impact of foreign ownership on both the likelihood of paying dividends and dividend payout ratio. The evidence may suggest that foreign investors invest in stocks for their long-run growth potential, rather than the short-term dividend income. This may also signify that foreign blockholders have the expertise and incentive to monitor corporate managers and thus their existence reduces the need for paying cash dividends as an internal disciplinary device. Consequently, BIST financials with higher percentage of foreign ownership pay none or lower dividends.

Finally, the results detect that board structure of financial firms influences their dividend policy decisions. More precisely, the proportion of independent directors on the board has a positive effect on the probability of paying a cash dividend but has no impact on how much to pay. This means that independent directors encourage BIST financials to distribute dividends to increase the dividend-induced capital market monitoring, perhaps due to their own inefficient direct monitoring exercises. In contrast, the results show that board size and the proportion of family directors on the board have no effect on the decisions to pay dividends, but - once firms opt for paying dividends - both of them are significant factors determining the amounts of dividend payouts. In this respect, larger boards are found to be associated with higher payouts (a positive effect). This may imply that large boards and dividends play complementary roles (rather than substitute devices) in enhancing monitoring and internal discipline. Yet, this may also infer that larger boards indicate weak monitoring since it could be more difficult to coordinate between large groups of directors, thus encouraging financial to pay higher 
dividends to increase dividend-induced monitoring. Family directors, however, lead to lower dividend payouts (a negative effect), which suggests that their direct involvement on the board increases the internal control and scrutiny, and therefore reduces the need for dividend-induced capital market monitoring.

Overall, the study results present that the major factors determining dividend policy decisions of BIST financial firms are quite similar to those of the industrial (non-financial) firms as identified by previous studies in the dividend literature. Considering the importance of the financial sector within the economy and given the different nature of financial corporations, the findings of this study could be beneficial for corporate managers, regulators and academic researchers, who seek useful guidance from relevant literature. As well, the findings could be valuable for internal and external investors while making investment decisions in the Turkish market. Along with identifying the most important factors affecting dividend policy of financial firms, this study also raises a question of whether financial institutions listed on the BIST follow managed dividend policies (i.e., stable dividends) or adopt residual dividend payments (i.e., paying out whatever remains after funding desired investment). However, this is an interesting topic left for future research.

\section{References}

Abdelsalam, O., El-Masry, A., and Elsegini, S. (2008). "Board Composition, Ownership Structure and Dividend Policies in an Emerging Market: Further Evidence from CASE 50," Managerial Finance, 34(12): 953-964.

Abreu, J.F. and Gulamhussen, M.A. (2013). "Dividend Payouts: Evidence from US Bank Holding Companies in the Context of the Financial Crisis," Journal of Corporate Finance, 22(1): 54-65.

Adaoğlu, C. (2000). "Instability in the Dividend Policy of the Istanbul Stock Exchange (ISE) Corporations: Evidence from an Emerging Market," Emerging Markets Review, 1(3): 252-270.

------, (2008). "Dividend Policy of the ISE Industrial Corporations: The Evidence Revisited (19862007)," Journal of BRSA Banking and Financial Markets, 2(2): 113-135.

Aivazian, V., Booth, L., and Cleary, S. (2003). "Do Emerging Market Firms Follow Different Dividend Policies from US Firms?,” Journal of Financial Research, 26(3): 371-387.

Aksu, M. and Kösedağ, A. (2006). "Transparency and Disclosure Scores and Their Determinants in the Istanbul Stock Exchange," Corporate Governance, 14(4): 277-296.

Al-Ajmi, J. and Abo Hussain, H. (2011). "Corporate Dividends Decisions: Evidence from Saudi Arabia," Journal of Risk Finance, 12(1): 41-56.

Allen, F. and Michaely, R. (2003). "Payout Policy," in Constantinides, G.M., Harris, M. and Stulz, R.M. (eds), Handbook of the Economics of Finance: 337-429. Amsterdam: Elsevier.

Al-Najjar, B. (2009). "Dividend Behaviour and Smoothing: New Evidence from Jordanian Panel Data," Studies in Economics and Finance, 26(3): 182-197.

Al-Najjar, B. and Kilincarslan, E. (2016). "The Effect of Ownership Structure on Dividend Policy: Evidence from Turkey," Corporate Governance, 16(1): 135-161.

, (2017). "Corporate Dividend Decisions and Dividend Smoothing: New Evidence from an Empirical Study of Turkish Firms," International Journal of Managerial Finance, 13(3): 304-331 
Al-Najjar, B. and Hussainey, K. (2009). "The Association between Dividend Payout and Outside Directorships," Journal of Applied Accounting Research, 10(1): 4-19.

Anderson, R.C. and Reeb, D. (2003). "Founding-Family Ownership and Firm Performance: Evidence from the S\&P 500," Journal of Finance, 58(3): 1301-1328.

Ashraf, B.N. and Zheng, C. (2015). "Shareholder Protection, Creditor Rights and Bank Dividend Policies," China Finance Review International, 5(2): 161-186.

Baker, H.K., Dutta, S., and Saadi, S. (2008). "Impact of Financial and Multinational Operations on Manager Perceptions of Dividends," Global Finance Journal, 19(2): 171-186.

Baker, H.K., Mukherjee, T.K., and Paskelian, O.G. (2006). "How Norwegian Managers View Dividend Policy," Global Finance Journal, 17(1):155-176.

Baker, H.K. and Powell, G.E. (1999). "How Corporate Managers View Dividend Policy," Quarterly Journal of Business and Economics, 38(2): 17-35.

Baker, H.K., Powell, G.E., and Veit, E.T. (2002). "Revisiting Managerial Perspectives on Dividend Policy," Journal of Economics and Finance, 26(2): 267-283.

Baker, M. and Wurgler, J. (2004). “A Catering Theory of Dividends,” Journal of Finance, 59(3): 1125-1165.

Barclay, M.J., Smith, Jr. C.W., and Watts, R.L. (1995). “The Determinants of Corporate Leverage and Dividend Policies," Journal of Applied Corporate Finance, 7(4): 4-19.

BAT. (2009). The Financial System and Banking Sector in Turkey. October 2009, Istanbul: The Bank Association of Turkey.

Bathala, C.T. and Rao, R.P. (1995). "The Determinants of Board Composition: An Agency Theory Perspective," Managerial and Decision Economics, 16: 59-69.

Beiner, S., Drobetz, W., Schmid, F., and Zimmermann, H. (2004). "Is Board Size an Independent Corporate Governance Mechanism?," Kyklos, 57(3): 327-356.

Bhattacharya, S. (1979). "Imperfect Information, Dividend Policy, and "The Bird in the Hand" Fallacy," Bell Journal of Economics, 10(1): 259-270.

Black, F. (1976). “The Dividend Puzzle,” Journal of Portfolio Management, 2(2): 5-8.

Boone, A.L., Field, L.C., Karpoff, J.M., and Raheja, C.G. (2007). “The Determinants of Corporate Board Size and Composition: An Empirical Analysis," Journal of Financial Economics, 85: 66-101.

Brealey, R.A. and Myers, S.C. (2003). Principles of Corporate Finance, $7^{\text {th }}$ edition. New York: McGraw-Hill.

Brennan, M. (1970). “Taxes, Market Valuation and Corporate Financial Policy,” National Tax Journal, 23: $417-427$.

Chen, Z., Cheung, Y-L., Stouraitis, A., and Wong, A.W.S. (2005). "Ownership Concentration, Firm Performance, and Dividend Policy in Hong Kong," Pacific-Basin Finance Journal, 13(4): 431-449.

Claessens, S., Djankov, S., and Lang, L.H.P. (2000). "The Separation of Ownership and Control in East Asian Corporations," Journal of Financial Economics, 58(1): 81-112.

CMB. (2003). Annual Report 2003. Ankara: Capital Markets Board of Turkey.

Collins, M.C., Blackwell, D.W., and Sinkey, Jr. J.F. (1995). "The Relationship between Corporate Compensation Policies and Investment Opportunities: Empirical Evidence for Large Bank Holding Companies," Financial Management, 24(3): 40-53. 
Crutchley, C.E. and Hansen, R.S. (1989). "A Test of the Agency Theory of Managerial Ownership, Corporate Leverage, and Corporate Dividends," Financial Management, 18(4): 36-46.

Dang, V.A. (2013). "An Empirical Analysis of Zero-Leverage Firms: New Evidence from the UK," International Review of Financial Analysis, 30: 189-202.

DeAngelo, H., DeAngelo, L., and Stulz, R.M. (2006). "Dividend Policy and the Earned/Contributed Capital Mix: A Test of the Life-Cycle Theory," Journal of Financial Economics, 81(2): 227-254.

Demsetz, H. and Lehn, K. (1985). "The Structure of Corporate Ownership: Causes and Consequences," Journal of Political Economy, 93(6): 1155-1177.

Dickens, R.N., Casey, K.M., and Newman, J.A. (2003). "Bank Dividend Policy: Explanatory Factors," Quarterly Journal of Business and Economics, 41(1/2): 3-12.

Dutta, A.S. (1999). "Managerial Ownership, Dividend and Debt Policy in the US Banking Industry," Managerial Finance, 25(6): 57-68.

Easterbrook, F.H. (1984). "Two Agency-cost Explanations of Dividends," American Economic Review, 74(4): 650-659.

Elton, E.J. and Gruber, M.J. (1970). "Marginal Stockholder Tax Rates and the Clientele Effect," Review of Economics and Statistics, 52(1): 68-74.

Ertürk, I. (2003). "Governance or Financialisation: The Turkish Case,” Competition and Change, 7(4): 185-204.

Faccio, M., Lang, L.H.P., and Young, L. (2001). "Dividends and Expropriation," American Economic Review, 91(1): 54-78.

Fama, E.F. (1980). "Agency Problems and the Theory of the Firm," Journal of Political Economy, 88(2): 288-307.

Fama, E.F. and French, K.R. (2001). "Disappearing Dividends: Changing Firm Characteristics or Lower Propensity to Pay?," Journal of Financial Economics, 60(1): 3-43.

Fama, E.F. and Jensen, M.C. (1983). "Separation of Ownership and Control," Journal of Law and Economics, 26(2): 301-325.

Farinha, J. (2003). "Dividend Policy, Corporate Governance and the Managerial Entrenchment Hypothesis: An Empirical Analysis,” Journal of Business Finance and Accounting, 30(9/10): 1173-1209.

Ferris, S.P., Sen, N., and Yui, H.P. (2006). "God Save the Queen and Her Dividends: Corporate Payouts in the United Kingdom," Journal of Business, 79(3): 1149-1173.

Fiegener, M.K., Brown, B.M., Dreux, D.R., and Dennis, W.J. (2000). "The Adoption of Outside Boards by Small Private US Firms," Entrepreneurship and Regional Development, 12: 291-309.

Frankfurter, G.M. and Wood, B.G. (2003). Dividend Policy: Theory and Practice. San Diego: Academic Press.

Gabrielsson, J. (2007). "Correlates of Board Empowerment in Small Companies," Entrepreneurship Theory and Practice, 31: 687-711.

Glen, J.D., Karmokolias, Y., Miller, R.R., and Shah, S. (1995). "Dividend Policy and Behaviour in Emerging Markets: To Pay or Not To Pay," IFC Discussion Paper 26. Washington DC: International Finance Corporation.

Gordon, M.J. (1959). "Dividends, Earnings and Stock Prices," Review of Economics and Statistics, 41(2): 99-105. 
Gordon, M.J. and Shapiro, E. (1956). "Capital Equipment Analysis: The Required Rate of Profit," Management Science, 3(1): 102-110.

Grinstein, Y. and Michaely, R. (2005). "Institutional Holdings and Payout Policy," Journal of Finance, 60(3): 1389-1426.

Grossman, S.J. and Hart, O.D. (1980). "Takeover Bids, the Free-rider Problem, and the Theory of the Corporation," Bell Journal of Economics, 11(1): 42-64.

Grullon, G., Michaely, R, and Swaminathan, B. (2002). "Are Dividend Changes a Sing of Firm Maturity," Journal of Business, 75(3): 387-424.

Gugler, K. (2003). "Corporate Governance, Dividend Payout Policy, and the Interrelation between Dividends, R\&D, and Capital Investment," Journal of Banking and Finance, 27(7): 1297-1321.

Gupta, M.C. and Walker, D.A. (1975). "Dividend Disbursal Practices in Commercial Banking," Journal of Financial and Quantitative Analysis, 10(3): 515-529.

Gürsoy, G. and Aydoğan, K. (1999). "Equity Ownership Structure, Risk-taking and Performance: An Empirical Investigation in Turkish Companies." Paper presented at the ERC/METU International Conference in Economics in Ankara.

Ho, H. (2003). "Dividend Policies in Australia and Japan," International Advances in Economic Research, 9(2): 91-100.

Holder, M.E., Langrehr, F.W., and Hexter, J.L. (1998). "Dividend Policy Determinants: An Investigation of the Influences of Stakeholder Theory," Financial Management, 27(3): 73-82.

IIF. (2005). Corporate Governance in Turkey - An Investor Perspective. Task Force Report. Washington DC: Institute of International Finance, Inc.

Imran, K. (2011). "Determinants of Dividend Payout Policy: A Case of Pakistan Engineering Sector," Romanian Economic Journal, 14(41): 47-60.

Imran, K., Usman, B., and Nishat, M. (2013). "Banks Dividend Policy: Evidence from Pakistan," Economic Modelling, 32(1): 88-90.

Jensen, G.R., Solberg, D.P., and Zorn, T.S. (1992). "Simultaneous Determination of Insider Ownership, Debt and Dividend Policies," Journal of Financial and Quantitative Analysis, 27(2): 247-263.

Jensen, M.C. (1986). “Agency Costs of Free Cash Flow, Corporate Finance and Takeovers," American Economic Review, 76(2): 323-329.

Jensen, M.C. (1993). “The Modern Industrial Revolution, Exit and Failure of Internal Control Systems," Journal of Finance, 48(3): 831-880.

Jensen, M.C. and Meckling, W.H. (1976). "Theory of the Firm: Managerial Behaviour, Agency Costs and Ownership Structure," Journal of Financial Economics, 3(4): 305-360.

Jeon, J.Q., Lee, C., and Moffett, C.M. (2011), "Effects of Foreign Ownership on Payout Policy: Evidence from the Korean Market," Journal of Financial Markets, 14(2): 344-375.

John, K. and Williams, J. (1985). "Dividends, Dilution, and Taxes: A Signalling Equilibrium," Journal of Finance, 40(4): 1053-1070.

Johnson, S., La Porta, R., Lopez-de-Silanes, F., and Shleifer, A. (2000). "Tunnelling," American Economic Review, 90(1): 20-27.

Khan, T. (2006). "Company Dividends and Ownership Structure: Evidence from UK Panel Data," Economic Journal, 116(510): C172-C189. 
Kilincarslan, E. and Özdemir, O. (2018). "Institutional Investment Horizon and Dividend Policy: An Empirical Study of UK Firms," Finance Research Letters, 24: 291-300.

Kirkulak, B. and Kurt, G. (2010). "Are Dividends Disappearing or Shrinking? Evidence from the Istanbul Stock Exchange," Emerging Markets Finance and Trade, 46(2): 38-52.

Kisman, Z. (2013). "Factors Influencing Dividend: Pay or Not to Pay on the Indonesia Stock Exchange," International Journal of Innovations in Business, 2(7): 670-715.

Kouki, M. and Guizani, M. (2009), "Ownership Structure and Dividend Policy Evidence from the Tunisian Stock Market," European Journal of Scientific Research, 25(1): 42-53.

La Porta, R., Lopez-de-Silanes, F., and Shleifer, A. (1999). "Corporate Ownership around the World," Journal of Finance, 54(2): 471-517.

La Porta, R., Lopez-de-Silanes, F., Shleifer, A., and Vishny, R.W. (2000). "Agency Problems and Dividend Policies around the World," Journal of Finance, 55(1): 1-33.

Lam, K.C.K., Sami, H., and Zhou, H. (2012). "The Role of Cross-listing, Foreign Ownership and State Ownership in Dividend Policy in an Emerging Market," China Journal of Accounting Research, 5(3): 199-216.

Lease, R.C., John, K., Kalay, A., Loewenstein, U., and Sarig, O.H. (2000). Dividend Policy: It's Impact on Firm Value. Boston MA: Harvard Business School Press.

Lintner, J. (1956). "Distribution of Incomes of Corporations among Dividends, Retained Earnings and Taxes," American Economic Review, 46(2): 97-113.

Litzenberger, R.H. and Ramaswamy, K. (1979). "The Effects of Personal Taxes and Dividends on Capital Asset Prices: Theory and Empirical Evidence," Journal of Financial Economics, 7: 163-195.

Lloyd, W.P., Jahera Jr., J.S., and Page, D.E. (1985). "Agency Costs and Dividend Payout Ratios," Quarterly Journal of Business and Economics, 24: 19-29.

Manos, R. (2002). "Dividend Policy and Agency Theory: Evidence on Indian Firms," Working Paper Series No. 41, Institute for Development Policy and Management, University of Manchester.

Miller, M.H. and Modigliani, F. (1961). "Dividend Policy, Growth and the Valuation of Shares," Journal of Business, 34(4): 411-433.

Miller, M.H. and Rock, K. (1985). "Dividend Policy under Asymmetric Information,” Journal of Finance, 40(4): 1031-1051.

Moh'd, M.A., Perry, L.G., and Rimbey, J.N. (1995). “An Investigation of the Dynamic Relationship between Agency Theory and Dividend Policy," Financial Review, 30(2): 367-385.

Morck, R., and Yeung, B. (2003). "Agency Problems in Large Family Business Groups," Entrepreneurship Theory and Practice, 27(4): 367-382.

Myers, S.C. (1984). “The Capital Structure Puzzle,” Journal of Finance, 39(3): 575-592.

Myers, S.C. and Majluf, N.S. (1984). "Corporate Financing and Investment Decisions When Firms Have Information That Investors Do Not Have," Journal of Financial Economics, 13(2): 187-221.

Public Disclosure Platform of Borsa Istanbul (KAP). (2017). BIST Companies, available at: https:// www.kap.org.tr/en/bist-sirketler

Rodriguez-Fernandez, M., Fernandez-Alonso, S., and Rodriguez-Rodriguez, J. (2014). "Board Characteristics and Firm Performance in Spain," Corporate Governance, 14(4): 485-503. 
Rozeff, M.S. (1982). "Growth, Beta and Agency Costs as Determinants of Dividend Payout Ratios," Journal of Financial Research, 5(3): 249-259.

Schellenger, M., Wood, D., and Tashakori, A. (1989). "Board of Director Composition, Shareholder Wealth, and Dividend Policy," Journal of Management, 15(3): 457-467.

Schooley, D.K. and Barney, Jr. L.D. (1994). "Using Dividend Policy and Managerial Ownership to Reduce Agency Costs," Journal of Financial Research, 17(3): 363-373.

Setia-Atmaja, L. (2010). "Dividend and Debt Policies of Family Controlled Firms: The Impact of Board Independence," International Journal of Managerial Finance, 6(2): 128-142.

Setia-Atmaja, L., Tanewski, G.A., and Skully, M. (2009). "The Role of Dividends, Debt and Board Structure in the Governance of Family Controlled Firms," Journal of Business Finance and Accounting, 36(7): 863-898.

Shleifer, A. and Vishny, R.W. (1986). "Large Shareholders and Corporate Control," Journal of Political Economy, 94(3): 461-488.

Shleifer, A. and Vishny, R.W. (1997). "A Survey of Corporate Governance," Journal of Finance, 52(2): 737-783.

Short, H., Zhang, H., and Keasey, K. (2002). "The Link between Dividend Policy and Institutional Ownership," Journal of Corporate Finance, 8: 105-122.

Smith, D.D., Pennathur, A.K., and Marciniak, M.R. (2017). "Why Do CEOs Agree to the Discipline Dividends?," International Review of Financial Analysis, 52: 38-48.

Smith, Jr. C.W. and Watts, R.L. (1992). "The Investment Opportunity Set and Corporate Financing, Dividend, and Compensation Policies," Journal of Financial Economics, 32: 263-292.

Sulong, Z. and Nor, F.M. (2008). "Dividends, Ownership Structure and Board Governance on Firm Value: Empirical Evidence from Malaysian listed Firms," Malaysian Accounting Review, 7(2): 55-94.

Theis, J. and Dutta, A.S. (2009). "Explanatory Factors of Bank Dividend Policy: Revisited," Managerial Finance, 35(6): 501-508.

Villalonga, B. and Amit, R. (2006). "How Do Family Ownership, Control and Management Affect Firm Value?," Journal of Financial Economics, 80(2): 385-417.

Wang, X., Manry, D., and Wandler, S. (2011). "The Impact of Government Ownership on Dividend Policy in China," Advances in Accounting, Incorporating Advances in International Accounting, 27(2): 366-372.

Wei, G., Zhang, W., and Xiao, J.Z. (2004). "Dividend Payment and Ownership Structure in China," Corporate Governance-Advances in Financial Economics, 9: 187-219.

Wei, Z., Wu, S., Li, C., and Chen, W. (2011). "Family Control, Institutional Environment and Cash Dividend Policy: Evidence from China," China Journal of Accounting Research, 4: 29-46.

Yarram, S.R. and Dollery, B. (2015). "Corporate Governance and Financial Policies: Influence of Board Characteristics on the Dividend Policy of Australian Firms," Managerial Finance, 41(3): 267-285.

Yoshikawa, T. and Rasheed, A.A. (2010). "Family Control and Ownership Monitoring in Family Controlled Firms in Japan,” Journal of Management Studies, 47(2): 274-295. 
Yurtoğlu, B.B. (2003). "Corporate Governance and Implications for Minority Shareholders in Turkey," Journal of Corporate Ownership \& Control, 1(1): 72-86.

Zeckhauser, R.J. and Pound, J. (1990). “Are Large Shareholders Effective Monitors? An Investigation of Share Ownership and Corporate Performance," in Hubbard, R.G. (ed), Asymmetric Information, Corporate Finance and Investment: 149-180. University of Chicago Press. 


\section{Appendix 1}

\section{List of the BIST Financial Firms included in the Study Sample}

\begin{tabular}{|c|c|c|c|}
\hline No & Company & Code & Sector \\
\hline 1 & Akbank T.A.Ş. & AKBNK & Banks and Special Finance Corporations \\
\hline 2 & Akfen Gayrimenkul Yatırım Ortaklığı A.Ş. & AKFGY & Real Estate Investment Trusts \\
\hline 3 & Akiş Gayrimenkul Yatırım Ortaklığı A.Ş. & AKSGY & Real Estate Investment Trusts \\
\hline 4 & Akmerkez Gayrimenkul Yatırım Ortaklığı A.Ş. & AKMGY & Real Estate Investment Trusts \\
\hline 5 & Aksigorta A.Ş. & AKGRT & Insurance \\
\hline 6 & Alarko Gayrimenkul Yatırım Ortaklığı A.Ş. & ALGYO & Real Estate Investment Trusts \\
\hline 7 & Alarko Holding A.Ş. & ALARK & Holding and Investment Companies \\
\hline 8 & Albaraka Türk Katılım Bankası A.Ş. & ALBRK & Banks and Special Finance Corporations \\
\hline 9 & Anadolu Anonim Türk Sigorta Şirketi & ANSGR & Insurance \\
\hline 10 & Anadolu Hayat Emeklilik A.Ş. & ANHYT & Insurance \\
\hline 11 & Ata Gayrimenkul Yatırım Ortaklığı A.Ş. & ATAGY & Real Estate Investment Trusts \\
\hline 12 & Atakule Gayrimenkul Yatırım Ortaklığı A.Ş. & AGYO & Real Estate Investment Trusts \\
\hline 13 & Avivasa Emeklilik ve Hayat A.Ş. & AVISA & Insurance \\
\hline 14 & Avrasya Gayrimenkul Yatırım Ortaklığı A.Ş. & AVGYO & Real Estate Investment Trusts \\
\hline 15 & Borusan Yatırım ve Pazarlama A.Ş. & BRYAT & Holding and Investment Companies \\
\hline 16 & Boyner Perakende ve Tekstil Yatırımları A.Ş. & BOYP & Holding and Investment Companies \\
\hline 17 & Creditwest Factoring A.Ş & CRDFA & Leasing and Factoring Companies \\
\hline 18 & Denge Yatırım Holding A.Ş. & DENGE & Holding and Investment Companies \\
\hline 19 & Denizbank A.Ş. & DENIZ & Banks and Special Finance Corporations \\
\hline 20 & Doğan Şirketler Grubu Holding A.Ş. & DOHOL & Holding and Investment Companies \\
\hline 21 & Doğuş Gayrimenkul Yatırım Ortaklığı A.Ş. & DGGYO & Real Estate Investment Trusts \\
\hline 22 & Eczacıbaşı Yatırım Holding Ortaklığı A.Ş. & ECZYT & Holding and Investment Companies \\
\hline 23 & $\begin{array}{l}\text { EİS Eczacıbaşı İlaç, Sınai ve Finansal Yatırımlar Sa- } \\
\text { nayi ve Ticaret A.Ş. }\end{array}$ & ECILC & Holding and Investment Companies \\
\hline 24 & Emlak Konut Gayrimenkul Yatırım Ortaklığı A.Ş. & EKGYO & Real Estate Investment Trusts \\
\hline 25 & Euro Yatırım Holding A.Ş. & EUHOL & Holding and Investment Companies \\
\hline 26 & Finansbank A.Ş. & FINBN & Banks and Special Finance Corporations \\
\hline 27 & Garanti Faktoring A.Ş. & GARFA & Leasing and Factoring Companies \\
\hline 28 & Global Yatırım Holding A.Ş. & GLYHO & Holding and Investment Companies \\
\hline 29 & Gözde Girişim Sermayesi Yatırım Ortaklığı A.Ş. & GOZDE & Holding and Investment Companies \\
\hline 30 & GSD Holding A.Ş. & GSDHO & Holding and Investment Companies \\
\hline 31 & Güneş Sigorta A.Ş. & GUSGR & Insurance \\
\hline 32 & Hacı Ömer Sabancı Holding A.Ş. & SAHOL & Holding and Investment Companies \\
\hline 33 & Halk Gayrimenkul Yatırım Ortaklığı A.Ş. & HLGYO & Real Estate Investment Trusts \\
\hline 34 & Hedef Girişim Sermayesi Yatırım Ortaklığı A.Ş. & HDFGS & Holding and Investment Companies \\
\hline 35 & ICBC Turkey Bank A.Ş. & ICBCT & Banks and Special Finance Corporations \\
\hline 36 & İhlas Holding A.Ş. & IHLAS & Holding and Investment Companies \\
\hline 37 & İhlas Yayın Holding A.Ş. & IHYAY & Holding and Investment Companies \\
\hline 38 & İş Finansal Kiralama A.Ş. & ISFIN & Leasing and Factoring Companies \\
\hline 39 & İş Gayrimenkul Yatırım Ortaklığı A.Ş. & ISGYO & Real Estate Investment Trusts \\
\hline
\end{tabular}




\section{Appendix 1 (continued)}

\begin{tabular}{|c|c|c|c|}
\hline No & Company & Code & Sector \\
\hline 40 & İş Girişim Sermayesi Yatırım Ortaklığı A.Ş & ISGSY & Holding and Investment Companies \\
\hline 41 & İş Yatırım Menkul Değerler A.Ş. & ISMEN & Banks and Special Finance Corporations \\
\hline 42 & Işı1klar Enerji ve Yapı Holding A.Ş. & IEYHO & Holding and Investment Companies \\
\hline 43 & İttifak Holding A.Ş. & ITTFH & Holding and Investment Companies \\
\hline 44 & Kiler Gayrimenkul Yatırım Ortaklığı A.Ş. & KLGYO & Real Estate Investment Trusts \\
\hline 45 & Koç Holding A.Ş. & KCHOL & Holding and Investment Companies \\
\hline 46 & Kombassan Holding A.Ş. & KOMHL & Holding and Investment Companies \\
\hline 47 & Martı Gayrimenkul Yatırım Ortaklığı A.Ş. & MRGYO & Real Estate Investment Trusts \\
\hline 48 & Metro Ticari ve Mali Yatırımlar Holding A.Ş. & METRO & Holding and Investment Companies \\
\hline 49 & Mistral Gayrimenkul Yatırım Ortaklığı A.Ş. & MSGYO & Real Estate Investment Trusts \\
\hline 50 & Net Holding A.Ş. & NTHOL & Holding and Investment Companies \\
\hline 51 & Nurol Gayrimenkul Yatırım Ortaklığı A.Ş. & NUGYO & Real Estate Investment Trusts \\
\hline 52 & Ostim Endüstriyel Yatırımlar ve İşletme A.Ş. & OSTIM & Holding and Investment Companies \\
\hline 53 & Özak Gayrimenkul Yatırım Ortaklığı A.Ş. & OZKGY & Real Estate Investment Trusts \\
\hline 54 & Özderici Gayrimenkul Yatırım Ortaklığı A.Ş. & OZGYO & Real Estate Investment Trusts \\
\hline 55 & Panora Gayrimenkul Yatırım Ortaklığı A.Ş. & PAGYO & Real Estate Investment Trusts \\
\hline 56 & PERA Gayrimenkul Yatırım Ortaklığı A.Ş. & PEGYO & Real Estate Investment Trusts \\
\hline 57 & Polisan Holding A.Ş. & POLHO & Holding and Investment Companies \\
\hline 58 & Reysaş Taşımacılık ve Lojistik Ticaret A.Ş. & RYGYO & Real Estate Investment Trusts \\
\hline 59 & Rhea Girişim Sermayesi Yatırım Ortaklığı A.Ş. & RHEAG & Holding and Investment Companies \\
\hline 60 & Sinpaş Gayrimenkul Yatırım Ortaklığı A.Ş. & SNGYO & Real Estate Investment Trusts \\
\hline 61 & Şekerbank T.A.Ş & SKBNK & Banks and Special Finance Corporations \\
\hline 62 & TAV Havalimanları Holding A.Ş. & TAVHL & Holding and Investment Companies \\
\hline 63 & Tekfen Holding A.Ş. & TKFEN & Holding and Investment Companies \\
\hline 64 & Torunlar Gayrimenkul Yatırım Ortaklığı A.Ş. & TRGYO & Real Estate Investment Trusts \\
\hline 65 & TSKB Gayrimenkul Değerleme A.Ş. & TSGYO & Real Estate Investment Trusts \\
\hline 66 & Türkiye Garanti Bankası A.Ş. & GARAN & Banks and Special Finance Corporations \\
\hline 67 & Türkiye Halk Bankası A.Ş. & HALKB & Banks and Special Finance Corporations \\
\hline 68 & Türkiye İş Bankası A.Ş. & ISCTR & Banks and Special Finance Corporations \\
\hline 69 & Türkiye Sınai Kalkınma Bankası A.Ş. & TSKB & Banks and Special Finance Corporations \\
\hline 70 & Türkiye Şişe ve Cam Fabrikaları A.Ş. & SISE & Holding and Investment Companies \\
\hline 71 & Türkiye Vakıflar Bankası T.A.O. & VAKBN & Banks and Special Finance Corporations \\
\hline 72 & Usaş Yatırımlar Holding A.Ş. & USAS & Holding and Investment Companies \\
\hline 73 & Vakıf Finansal Kiralama A.Ş. & VAKFN & Leasing and Factoring Companies \\
\hline 74 & Vakıf Gayrimenkul Yatırım Ortaklığı A.Ş. & VKGYO & Real Estate Investment Trusts \\
\hline 75 & Verusa Holding A.Ş. & VERUS & Holding and Investment Companies \\
\hline 76 & Yapı Kredi Koray G.Y.O. A.Ş. & YKGYO & Real Estate Investment Trusts \\
\hline 77 & Yapı ve Kredi Bankası A.Ş. & YKBNK & Banks and Special Finance Corporations \\
\hline 78 & Yazıcılar Holding A.Ş. & YAZIC & Holding and Investment Companies \\
\hline 79 & Yeni Gimat Gayrimenkul Yatırım Ortaklığı A.Ş. & YGGYO & Real Estate Investment Trusts \\
\hline 80 & Yeşil Gayrimenkul Yatırım Ortaklığı A.Ş. & YGYO & Real Estate Investment Trusts \\
\hline
\end{tabular}




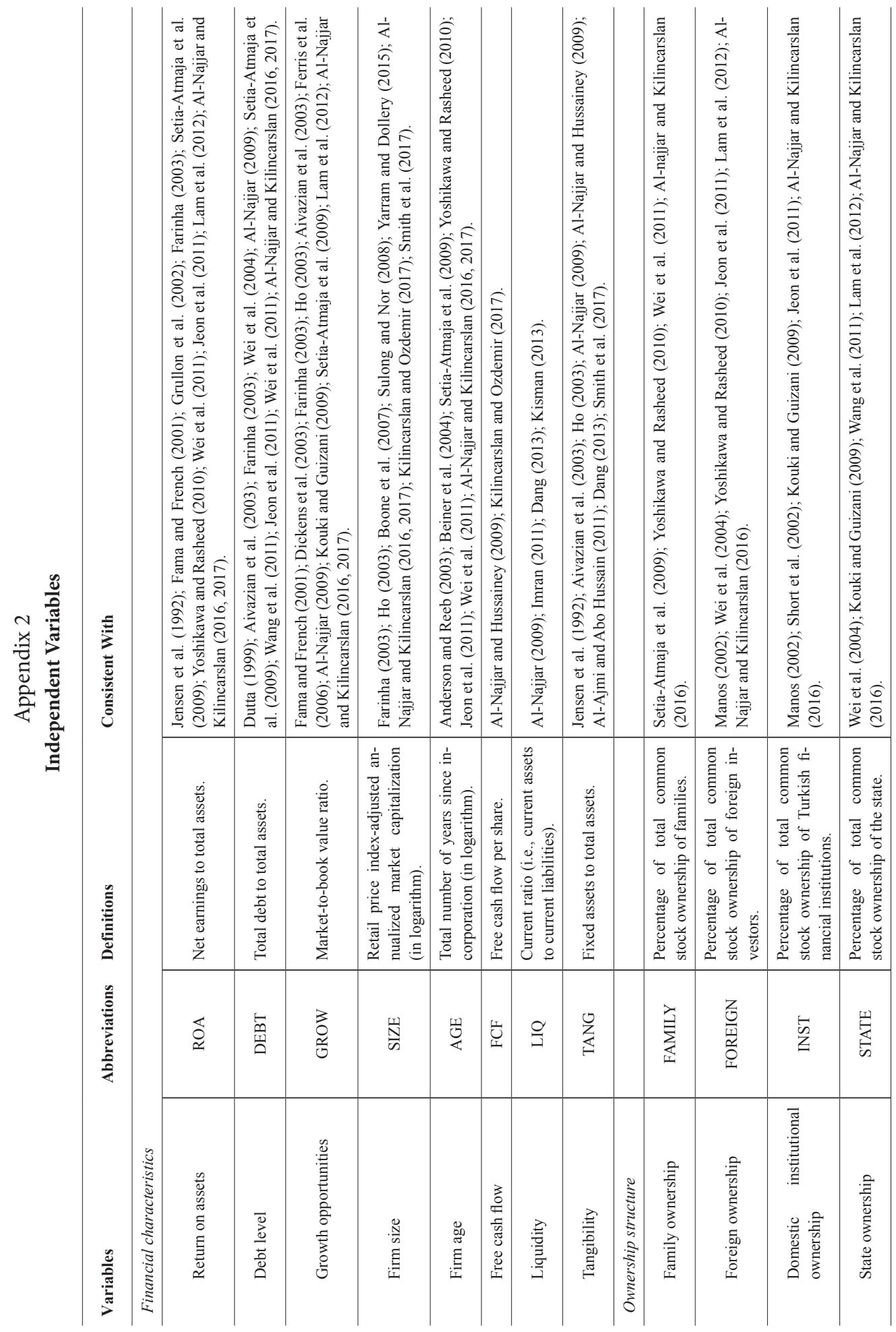




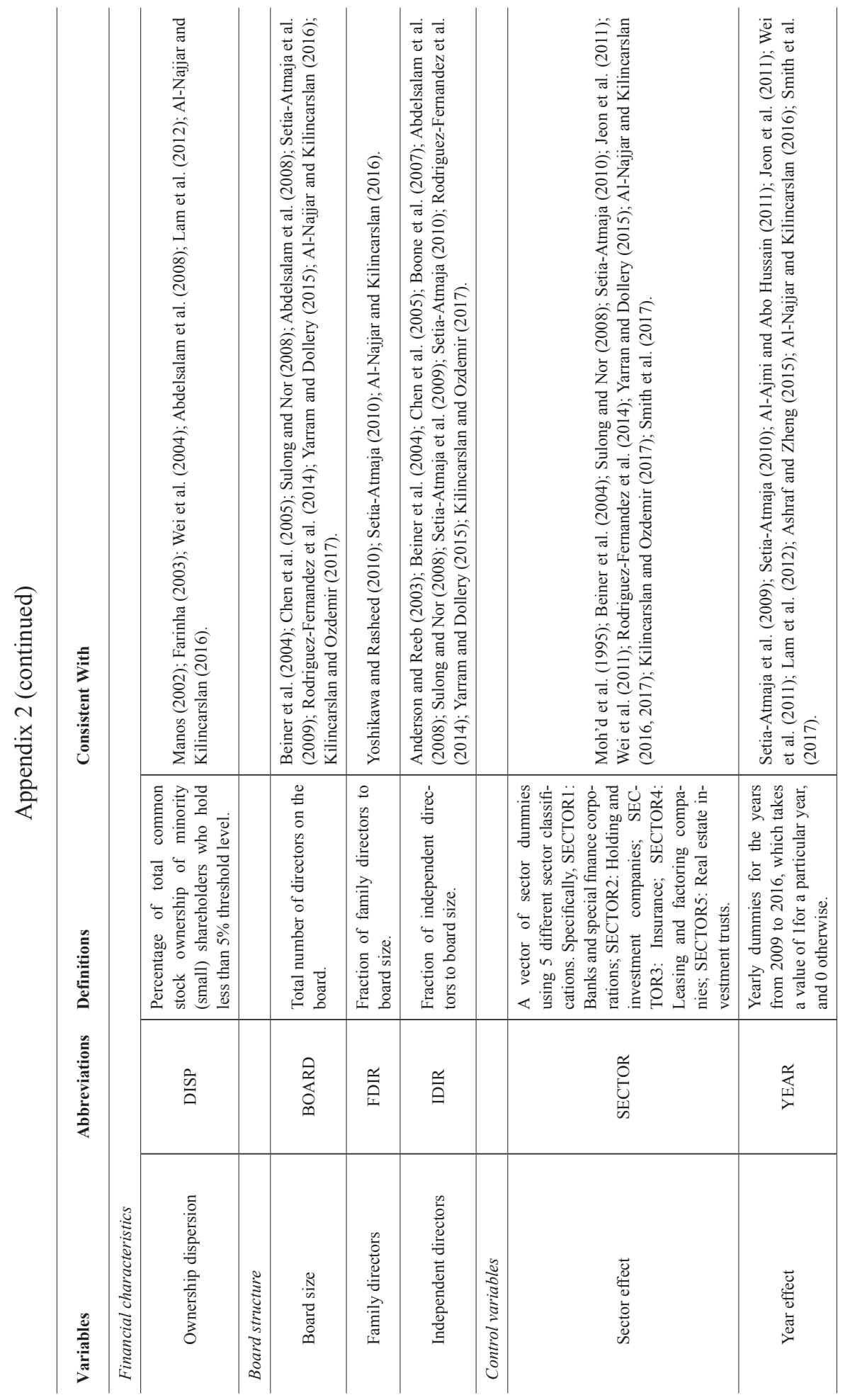

